This is an electronic reprint of the original article. This reprint may differ from the original in pagination and typographic detail.

Author(s): Lindholm-Lehto, Petra; Knuutinen, Juha; Ahkola, Heidi; Herve, Sirpa H.

Title: $\quad$ Refractory organic pollutants and toxicity in pulp and paper mill wastewaters

Year: $\quad 2015$

Version:

Please cite the original version:

Lindholm-Lehto, P., Knuutinen, J., Ahkola, H., \& Herve, S. H. (2015). Refractory organic pollutants and toxicity in pulp and paper mill wastewaters. Environmental Science and Pollution Research, 22(9), 6473-6499. https://doi.org/10.1007/s11356015-4163-x

All material supplied via JYX is protected by copyright and other intellectual property rights, and duplication or sale of all or part of any of the repository collections is not permitted, except that material may be duplicated by you for your research use or educational purposes in electronic or print form. You must obtain permission for any other use. Electronic or print copies may not be offered, whether for sale or otherwise to anyone who is not an authorised user. 


\title{
Organic pollutants and toxicity in pulp and paper mill wastewaters
}

\author{
Petra C. Lindholm-Lehto, ${ }^{\mathrm{a}, *}$ Juha S. Knuutinen, ${ }^{\mathrm{a}}$ Heidi S. J. Ahkola, ${ }^{\mathrm{b}}$ and Sirpa H. Herve ${ }^{\mathrm{b}}$
}

This review describes medium and high molecular weight organic material found in wastewaters from pulp and paper industry. The aim is to review the versatile pollutants and the analysis methods for their determination. Among other pollutants, biocides, extractives and lignin derived compounds are major contributors to harmful effects, such as toxicity, of industrial wastewaters. Toxicity of wastewaters from pulp and paper mills is briefly evaluated including the methods for toxicity analyses. Traditionally, wastewater purification includes mechanical treatment followed by chemical and/or biological treatment processes. A variety of methods are available for the purification of industrial wastewaters, including aerobic and anaerobic processes. However, some fractions of organic material, such as lignin and its derivatives are difficult to degrade. Therefore, novel chemical methods, including electrochemical and oxidation processes, have been developed for separate use or in combination with biological treatment processes.

Keywords: Biocides; Extractives; Fatty acids; Lignin; Organic Pollutants; Resin acids; Toxicity; Wastewaters

Contact information: a: Department of Chemistry, University of Jyväskylä, P.O. Box 35, FI-40014 University of Jyväskylä, Finland; b: Finnish Environment Institute (SYKE), Laboratory Centre, Ecotoxicology and Risk Assessment, Survontie 9A, FI-40500 Jyväskylä, Finland

*Corresponding author: petra.lindholm-lehto@jyu.fi

\section{INTRODUCTION}

Surface waters receive large quantities of waste water from industrial, agricultural and domestic sources (Ohe et al. 2004; Vincent-Hubert et al. 2012). For example, river waters in Europe and other industrialized regions are strongly contaminated by the chemicals, such as polycyclic aromatic hydrocarbons (PAHs) and polychlorinated biphenyls (PCBs) but also trace amounts of various chemicals, such as pharmaceuticals originating from treated wastewaters of industrial and urban sources (Ohe et al. 2004; Vincent-Hubert et al. 2012; Lindholm et al. 2014). More than 100000 metric ton of chemicals are annually released directly or indirectly into aquatic environment. These surface waters are used as a source of drinking water. Therefore, water pollution can be a serious problem to aquatic ecosystem and public health.

Effluents from pulp and paper industry contain complex matrices and a high number of diverse compounds (Latorre et al. 2003). Pulp and paper mill effluents can contain over 250 identified chemicals, including harmful components, such as resin acids and sterols (Ratia et al. 2012; 2013). In the water bodies, these compounds end up in sediments from which they are available to fish and benthos (Meriläinen and Oikari 2008). Even though most of the harmful substances are removed by the modern wastewater purification processes, some are still released into the environment. In addition, sediments are contaminated during previous decades and pose a risk if they act as a source of contaminants due to re-suspension (Rämänen et al. 2010). For example, previously 
untreated effluent with wood-derived bioactive substances and heavy nutrient load released into natural waters cause oxygen depletion and decline of diversity of species (Hynynen et al. 2004).

Traditionally, industrial wastewaters have been treated with mechanical technologies followed by biological and/or chemical methods. However, wastewaters from pulp and paper mills contain recalcitrant organic material, such as lignin and lignin derivatives which raise the need for additional treatment methods. Therefore, variety of novel chemical methods has been introduced, such as oxidation processes and electrochemical processes (Cuzzola et al. 2002). For example, oxidation of effluents aims at degradation of organic pollutants and their complete mineralization. On the other hand, by electrochemical methods even the smallest flocs can be removed from the effluent and reduce the amount of lignin, phenols, biochemical oxygen demand (BOD) and chemical oxygen demand (COD) (Uğurlu et al. 2008). These methods can be applied separately or combined with e.g. biological treatments.

The input of pulp and paper mill effluents to the water toxicity has been well recognized (Thompson et al. 2001). This review highlights the main organic material in the effluents of pulp and paper industry. In addition, their toxicity and methods of analyses are discussed. The aim is also briefly to introduce chemical treatment methods available separately or in combination with biological processes for the processing of recalcitrant material in pulp and paper mill effluents.

\section{COMPONENTS IN PULP AND PAPER MILL WASTEWATERS}

Large amount of freshwater is needed in the pulp and paper industry (Savant et al. 2006; Lei et al. 2013). In order to produce a ton of paper, about $60 \mathrm{~m}^{3}$ of water is required even with the most efficient process techniques. Therefore, a large amount of wastewater is generated by the pulp and paper mills (Vepsäläinen et al. 2011). Pollutants are produced during different process stages, such as wood debarking, pulp washing and bleaching (Ali and Sreekrishnan 2001). The wastewater often contains toxic chemicals, such as resin acids, tannins and chlorinated organic compounds which can be harmful to animals and cause e.g. mutagenicity and genotoxicity. In the boreal latitudes, the chemical wood industry is the most significant line of industry disturbing aquatic environment (Ratia et al. 2012).

Historically, pulp and paper mill wastewaters have been a major contributor of pollutant discharges to the environment (Saski et al. 1997; Thompson et al. 2001). However, the amount of adsorbable organic halides (AOX) decreased rapidly after replacing the elemental chlorine by elemental chlorine free $(\mathrm{ECF})$ or total chlorine free (TCF) bleaching and introducing biological wastewater treatment (Leiviskä et al. 2008). Due to the legislative pressure and advanced techniques, the paper industry has reduced its environmental effects over decades to air, water and land by 80-90\% (Thompson et al. 2001). In addition, the water consumption has been reduced which has forced to develop more efficient methods for pulp washing. However, the remaining discharge still represents a major input of organic contaminants into the freshwaters.

Traditionally, the discharge standards are defined based on the chemical and biochemical characteristics, such as BOD, COD, AOX, ammonium nitrogen $\left(\mathrm{NH}_{4}-\mathrm{N}\right)$, phenol, sulfur, Fe, Cr, oil, and grease (Sponza 2003). However, conventional toxicity tests based on bacteria or algae are not considered. The untreated wastewaters from paper and 
board mills are potentially very toxic including COD as high as $11000 \mathrm{mg} / \mathrm{L}$ (Thompson et al. 2001). The water consumption varies according to used processes, chemicals and the type of paper produced. It can be as high as $60 \mathrm{~m}^{3}$ per ton of paper even with the most advanced process techniques although commonly a certain degree of water is recycled (Lin et al. 2013). However, the recovery and re-use of water increases the concentrations of organic and inorganic substances in the mill water which can affect the paper formation, increase bacterial growth and lead to corrosion of process equipment (Robertson and Schwingel 1997). Commonly, the pulp wastewater contains dissolved wood derived substances extracted during the pulping and bleaching processes.

The toxic effluents from the bleach plant include chlorinated organic compounds originating from the bleaching process (Savant et al. 2006). About 500 different chlorinated organic compounds have been identified so far including resin acids, chlorinated hydrocarbons, phenols, dioxins and furans. In wastewaters, these are measured collectively as AOX. The organic halides can be further divided into high molecular weight (HMW, MW $>1 \mathrm{kDa}$ ) and low molecular weight (LMW, MW $<1 \mathrm{kDa}$ ) compounds (Kringstad and Lindström 1984). The chlorinated compounds are a matter of concern due to their recalcitrance to biological degradation, toxicity to aquatic organisms, gonotoxicity and potential to accumulate (Sponza 2003).

The organic material before and after the activated sludge treatment is in the HMW range $(<10 \mathrm{kDa}$ ) (Leiviskä et al. 2008). The $6 \mathrm{kDa}$ fraction is the most significantly reduced by the activated sludge process. However, the treated effluent contains biorecalcitrant organics, such as aromatic and lignin-related substances. These compounds mineralize to lesser extent during the biological treatment and contribute to the main part of the residual COD in the effluent. For example, $60 \%$ of AOX in the effluent of bleached kraft pulp mill is transformed and degraded to smaller fractions in an aqueous environment in a year (Saski et al. 1997). A minor part (0.2-14\%) is recovered in sediments. The molecular weight and polarity of substances are important factors for evaluation of the environmental behavior.

Biological treatment is largely used to treat pulp and paper mill wastewaters and remove organic material and decrease the COD content (Leiviskä et al. 2012). However, it can only partially remove the decolorization of water. The wastewater also contains other organic components, such as lignin and its derivatives which biodegrade reluctantly (Leiviskä et al. 2008). In addition, transformation of these compounds into other toxic compounds during the biological treatment may occur. Even at low concentrations, wood extractives can cause toxic and hormonal effects on the aquatic organisms (Oikari et al. 1983; Mörck et al. 2000).

The effluents of chlorine bleaching are toxic due to chlorine containing organic compounds (Sponza 2003). Large part of the COD content is caused by the synthetic HMW bleaching agents and dyes. In addition, dyes may contain high levels of AOX. Chlorinated pulping effluents impair the quality of fish and fish flesh in the receiving waters (Herve 1991; Redenbach 1997). The chlorophenols are problematic also because of their lipophilicity and persistence in the environment. They accumulate into the river sediments and bioaccumulate in the tissues of organisms (Dyer and Mignone 1983). The bleach plant effluents have caused disorders in fish, such as sublethal chronic responses and reduced tolerance (Demirbaş et al. 1999). 


\section{BOD}

The BOD test gives information about the oxygen demand of wastewater even though it is not specific to a certain pollutant (Pepper et al. 1996; Kumar et al. 2010). The BOD test has two stages of which the first, i.e. carbonaceous stage, represents the oxygen demand in the conversion of organic carbon to $\mathrm{CO}_{2}$ at $21^{\circ} \mathrm{C}$ in five or seven days. The BOD value is the sum of the oxygen demand of the microorganisms over the time period. In the second stage the bacterial biomass is further degraded to $\mathrm{CO}_{2}$ and protozoan biomass. Since the results depend on the microorganism used, the repeatability of the test remains poor. The samples need to be seeded with a standardized population of microorganisms because the amount of microorganisms in different samples varies greatly.

Microorganisms for the seeding are often procured from sewage or activated sludge (Desai 1992). However, variations in BOD values occur when bacterial populations from different sources are used. This can be caused by the variations in the types and number of microbes in the samples. Some wastes can be poisonous to the microorganisms while other microorganisms are adapted to toxic conditions. BOD values of pulp and paper wastewaters can be misleading if the wastewater contains compounds that are not degraded by the bacteria in question. Therefore, a uniform microbial seed must be used for pulp and paper wastewater which is able to degrade the compounds in the sample (Sharma et al. 1996). With nonspecific bacteria only a partial assimilation of the organic matter will occur and lower BOD test values will be indicated.

\section{Lignin}

The components in pulp and paper mill wastewaters are often aromatic including lignin and its chlorinated derivatives (Allen et al. 2001). Lignin is the second most common natural polymer after the cellulose (Sjöström 1984; Kringstad and Lindström 1984). By quantity, it is the biggest waste product produced by the chemical pulping process. For example, the average molecular weight for softwood lignin is about $20 \mathrm{kDa}$ (Sjöström 1984). Lignin can be divided by its origin to softwood lignin, hardwood lignin and nonwood lignin. In addition to natural lignin, a variety of its derivatives, such as chlorinated lignin, is formed during chemical pulping and bleaching processes (Ali and Sreekrishnan 2001). It is modified and depolymerized by the pulping and bleaching chemicals which results a complex mixture of soluble lignin fragments.

Lignin is the product of enzymatic hydrogenation and polymerization of phenyl propane type alcohols forming a mixture of different polymers (Adler 1977). The precursors of lignin are $p$-hydroxy phenyl propenol, guaiacyl propenol and syringyl propenol. The amount of each varies according the type of lignin. For example, the softwood lignin is over $90 \%$ is composed of guaiacyl propenol and $10 \%$ of $p$-hydroxy phenyl propenol units. On the other hand, hardwood lignin is composed of guaiacyl and syringyl propenol units in different proportions (Sjöström 1984).

Typically, large molecules like lignin have been considered to be biologically inert and non-toxic to organisms (Paasivirta et al. 1988; Maatela et al. 1990; Pessala et al. 2010). A molecule with large molecule size $(>2 \mathrm{kDa})$ is biologically inactive because they are too large to penetrate into cells. However, there are indications that lignin derivatives exhibit slightly toxic potential when measured with the rapid screening method, i.e. the RET assay (Pessala et al. 2010). Especially phenolic hydroxyl groups of lignin may be important for biological effects. For example, sodium lignosulfonates have been reported to be low in acute and sub-acute toxicity (Sastry 1986; Sierra-Alvarez and Lettinga 1991). On the other hand, there are studies showing lignin and its derivatives are toxic to organisms and 
animals (Leach 1980; Priha and Talka 1986). Undiluted pulp mill effluents are acutely toxic and mutagenic to aquatic organisms (Ali and Sreekrishnan 2001). However, chlorinated phenolics and chlorinated lignin derivatives are the chemicals mostly responsible for the toxicity of pulp and paper effluents. Chlorinated phenolics represent only $2 \%$ of organically bound chlorine in bleaching effluents but are large contributors to effluent toxicity (Heimberger et al. 1988; Kukkola et al. 2011). In addition, products of lignin oxidation, such as 1,2-dihydrobenzene, have been identified responsible for the mutagenic properties of pulp bleaching plant effluents (Sponza 2003).

Lignin is one of the substances most difficult to degrade (Kumar et al. 2010). For example, lignosulfonates are found to inhibit several biological systems, such as functions of enzymes, toxins and antibiotics and the chlorinated derivatives of lignin are poorly degraded by the conventional wastewater treatment processes (Farstad and Naess 1977; Sponza 2003). Lignin and its derivatives degrade very slowly with conventional biological processes due to strong linkages in the lignin molecule, such as biphenyl-type carbon to carbon bonds (Ali and Sreekrishnan 2001; Lei et al. 2013). Lignin molecules tend to undergo self-condensation especially in acidic media showing resistance to degradation. In addition, the double bonds conjugated to an aromatic ring, quinone groups and quinone methides are responsible for the visible color (Sarkanen and Ludwig 1971). The colored effluent is not only an aesthetic problem but also cause changes in the algal and aquatic plant productivity due to reduced penetration of solar radiation.

Chlorinated lignin is composed of aliphatic, partly bridged chains with conjugated double bonds including acidic and alcoholic groups. The amount of phenolic groups varies according to wood species. Chlorinated lignin is mostly aliphatic but has also aromatic structures (Kringstand and Lindström 1984). However, chlorinated lignin has low contents of methoxy and hydroxy groups but a high carboxylic content (Ali and Sreekrishnan 2001). The characterization of chlorinated lignin is difficult because the common analysis methods, such as GC-MS and LC-MS are not suitable for the analysis of such a structurally complex and high molecular weight compound.

The fate of chlorinated lignin in the environment is not entirely known (Maatela et al. 1990). However, its behavior e.g. in sedimentation, biodegradation and bioaccumulation is comparable to the molecular size and functional groups. In addition, it is known that a major part of chlorinated lignin is concentrated into the sediment in aqueous environment. Chlorinated lignin is degraded in the aquatic environment very slowly by chemical and bacterial degradation (Kringstad and Lindström 1984). During the biological and chemical degradation of chlorinated lignin can be formed small (MW $<1 \mathrm{kDa}$ ) detrimental compounds, such as chloroanisoles and chloroveratroles (Paasivirta et al. 1987; Herve 1991). For example, the accumulation of these compounds into fish may cause ill taste. Chlorinated lignin can also bind very lipophilic compounds (Kukkonen 1992).

Chlorinated lignin is only partially degraded during the biological wastewater treatment and often led unchanged into the environment (Brezny et al. 1993). The concern is that the chlorinated lignins release toxic or bioaccumulative compounds or alter into biologically active compounds. Chlorinated phenols are spontaneously released from chlorinated lignin in the aqueous conditions. The compounds in the sludges may have detrimental impacts on vegetation (Popa and Teaca 1998). For example, chlorinated lignin has an adverse effect on the germination of wheat. On the long term, plants can adapt to polluted environment. However, chlorinated lignin has limited mobility in the soil and decreased bioaccumulation ability. Chlorinated lignin mineralizes into chlorides after being released into the soil (Brezny et al. 1993). 


\section{Color}

All pulping effluents are often highly colored due to the dissolved lignin and complex dissolved organic material (DOM) (Tuomela et al. 2000; Ali and Sreekrishnan 2001; Thompson et al. 2001). The coloring is more pronounced with chemical pulping methods. In addition, papermaking effluents may have some discoloration, especially when dyes are used to produce colored paper. The brownish color is caused mostly by lignin, its derivatives and polymerized tannins which are difficult to degrade. These substances are released from pulping, bleaching and recovery stages.

The pulp is originally brown in color and is bleached to increase its brightness (Ali and Sreekrishnan 2001). Bleaching is performed in several stages including those with chlorine in different forms. In addition to chlorine dioxide, oxygen, ozone and hydrogen peroxide are often employed. Chlorine reacts with lignin and other organic material present in pulp forming chlorinated compounds (Kringstand and Lindström 1984). Therefore, chlorinated lignosulfonic acids, chlorinated resin acids, chlorinated phenols and chlorinated hydrocarbons can be found in bleaching effluents. Most of the chlorolignins are formed in the first bleaching stage and can be found from the effluent of the first alkaline extraction stage. Therefore, the effluent is strongly colored and has a high AOX, BOD and COD content (Sun et al. 1989).

The effluents from the wood debarking are highly colored due to lignin, lignin derivatives and tannins which are known to be toxic to bacteria and fish (Sarkanen and Ludwig 1971; Temmink et al. 1989; Sierra-Alvarez et al. 1994). In the kraft process, lignin is converted to thio- and alkaline lignin (Ali and Sreekrishnan 2001). On the other hand, lignosulfates are formed in the sulfite process. Chlorinated phenols and chlorinated lignin derivatives are the main compounds responsible for the toxicity of pulp and paper mill effluents (Walden and Howard, 1977). Lignin and its derivatives give an unpleasant smell and color but also inhibit the natural photosynthesis by absorbing solar light (Sastry 1986). Lignin causes discolored and brownish water which reduces the photosynthesis and formation of phytoplankton. This can cause imbalance of oxygen and nutrients which has an effect on the aquatic ecosystem.

Aerobic or anaerobic biological treatments have little or no effect on color removal (Lei et al. 2013). Colored substances are not removed or degraded during the biological treatment and the effluent color can even be increased instead. The increased color may be caused by the abundant presence of carbonyl and hydroxyl groups after the biological treatment. HMW material can be removed by coagulation, more efficiently than LMW compounds and expected to minimize formation of colored material when used prior to anaerobic sludge bed (ASB) reactor treatment (Matilainen et al. 2010). However, the unremoved compounds cause increased color formation during the ASB treatment (Lewis et al. 2011). The amount of colored material increases due to conversion of organic material into smaller chromatographic units instead of mineralization or removal of organic matter during the biological treatment (Tuomela et al. 2000; Lewis et al. 2013).

Physical and chemical methods remove HMW chlorinated lignins, color, toxicity, suspended solids and COD but are quite expensive (Ali and Sreekrishnan 2001). Biological methods degrade the polymeric lignin-derived chromophoric material if several different classes of microbes are used. Physical and chemical methods include rapid filtration through soil, ultrafiltration, ion-exchange chromatography, lime precipitation and modified bleaching, such as peroxide addition during extraction stage. However, they are expensive and not commercially viable. In addition, with these methods lignin undergoes spatial change instead of chemical one and the problem remains in different form. 
Several bacteria have been tested for the removal of color in wastewater (Ali and Sreekrishnan 2001). For example, Pseudomonas aeruginosa can reduce kraft mill effluent color by $26-54 \%$ under aerobic conditions. The color is mainly removed by adsorption and only a little depolymerization occurs. Only a few strains are able to attack lignin derivatives. Some algae, such as Microcystis sp. can decolorize kraft pulp effluents (Lee et al. 1978). Both pure and mixed algal cultures can remove up to $70 \%$ of the color within two months of incubation but the first 15-20 days are the most effective. Color removal by algae is caused by the metabolic transformation or degradation of colored molecules. Among microbes, fungi and especially the white rots are the most efficient degraders of lignin. For example, S. commune can remove color by $90 \%$ under optimum conditions during two days of incubation (Belsare and Prasad 1988).

\section{Chlorophenols}

The physical properties of chlorophenols vary greatly, depending on the number of chlorine atoms and their position relative to hydroxyl group which complicates their simultaneous determination (de Morais et al. 2012). Generally, chlorophenolic compounds are volatile, lipophilic compounds. They are industrially produced and act as the effective substance e.g. in insecticides, fungicides and herbicides (Paasivirta 1978). Chlorophenols are also formed during pulping and bleaching forming bioaccumulative and toxic compounds (Holmbom 1980). Chlorophenols are derived by the action of chlorine and its hydrolyzed derivatives which are formed during the breakdown of lignin in the pulping process (Butler and Dal Pont 1992). The amount of chlorophenols formed depends on the ratio of chlorine and chlorine dioxide but also on the ratio of softwood and hardwood (Kringstad and Lindström 1984; Kitunen 1990). Typically, there are polychlorinated guaiacols and catechols in bleached pulp mill effluents in addition to other chlorophenolic compounds (Fig. 1) (Häggblom et al. 1988; Herve 1991). Chloroguaiacols originate mainly from the first alkali extraction step and chlorocathecols from the first chlorination step (Landner et al. 1977).

Chlorophenols in pulp bleaching are both in free and bound forms in dissolved organic matter and particles (Paasivirta et al. 1992; Palm et al. 1995). Chloroguaiacols and cathecols can be biologically methylated to anisoles and veratroles during effluent treatment or later in the environment (Häggblom et al. 1988). A part of chlorinated compounds in pulp mill effluents have been found to degrade in recipient water (Remberger et al. 1986; Paasivirta et al. 1988). However, chlorinated guaiacols and catechols can preserve for a long time in sediments. In addition, chloroguaiacols can spread very far from the discharging point (Grimvall et al. 1991).
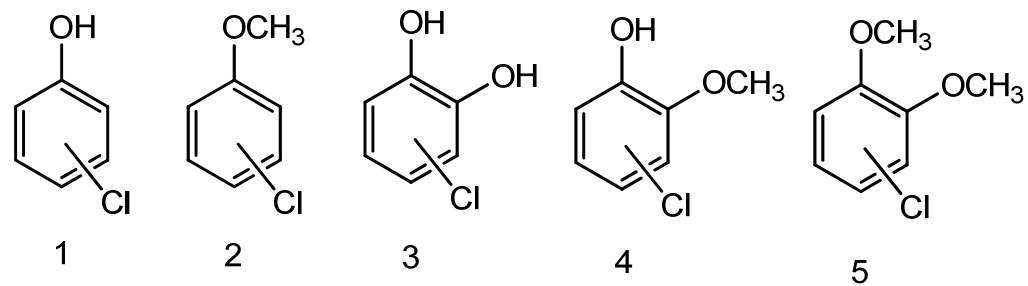

Fig. 1 General formulas of chlorophenols (1), chloroanisoles (2), chlorocathecols (3), chloroguaiacol (4) and chloroveratroles (5)

Chlorophenols are toxic chemicals with estrogenic, mutagenic and carcinogenic effects (Michałowicz and Duda 2007). Additionally, they have a high acute toxicity, can 
interfere oxidative phosphorylation and inhibit ATP synthesis. Chlorophenols may also act as precursors of extremely toxic dioxins and furans either upon incineration or after metabolism in humans (Veningerová et al. 1993; Criado et al. 2004). Due to their lipophilic properties, the chlorophenols tend to sorb onto solid material and accumulate into soils, sediments and sludge (de Morais et al. 2012). In addition, they show toxic properties on fish (Oikari et al. 1988). In addition to chlorophenols, chloroguaiacols are highly toxic and more toxic in limnic than in marine conditions or in brackish water systems (Renberg et al. 1980). Chlorinated anisoles and veratroles are toxic and bioaccumulative and also potential for causing off-flavors in receiving water and fish (Brownlee et al. 1993). Chlorinated anisoles are typically several orders of magnitude more potential odor compounds than chlorinated phenols and many of them have low odor threshold concentrations in water (Griffiths and Fenwick 1977; Paasivirta et al. 1983). However, volatility is not the major determinant of odor threshold but the structural factors are more important.

\section{Dioxins and related pollutants}

Polychlorinated dibenzodioxins (PCDDs), polychlorinated dibenzofurans (PCDFs) and dioxin-like polychlorinated biphenyls (PCBs) are structurally and chemically related halogenated aromatic hydrocarbons (Davy 2004; Srogi 2008). PCDDs and PCDFs form a group of 210 different congeners, including 135 PCDFs and 75 PCDDs (Fig. 2). On the other hand, there are 209 possible isomers of PCBs but only 100 of them are likely to occur in industrial PCB mixtures (Pomerantz et al. 1978). There are Dioxins are toxic and classified by United Nations Environment Programme (UNEP) as "some of the most dangerous chemicals on earth" (Davy 2004). All PCDDs and PCDFs are solids with high melting points and low vapour pressures. They have extremely low water solubilities and have strong tendency being absorbed in particulate surfaces. The water solubility decreases as the chlorine content increases. Isomers with chlorine in 2,3,7,8 positions (7 PCDDs and 10 PCDFs) are the most toxic to organisms of which 2,3,7,8 tetrachlorodibenzo- $p$-dioxin (TCDD) being the most toxic (Malisch 2000; Fueno et al. 2002).

Dioxins are persistent in nature due to their lipophilic properties and resistance to biological and chemical degradation (Vallejo et al. 2015). This leads to biomagnification along food chains and various degrees of toxic effects (Van der Berg et al. 2006). Due to their persistent nature, they are transported away from their emission sources. Dioxins can be formed via degradation of carbon species in the presence of a chlorine source at temperature range $200-600{ }^{\circ} \mathrm{C}$. On the other hand, they can be formed via precursor compounds, such as pentachlorophenol chlorinated diphenylethers and polychlorinated biphenyls or chlorobenzenes which are used as fungicidal and bacterial agent in wood treatment (Weber 2007; Holt et al. 2008).

Dioxins have never been intentionally produced but are released to the environment as unwanted by-products from chemical processes, such as chlorine bleaching of pulp and paper, manufacture of pesticides, herbicides and fungicides (Chen 2004; Vallejo et al. 2015). Small amounts are generated during volcanic eruptions and forest fires (Freeman and de Tejada 2002). However, far greater amounts of dioxins and furans are released from the man-made sources and activities than natural processes (El-Shahawi et al. 2010). For example, dioxins and furans may originate also from pentachlorophenol-based (PCP) fungicides including penta- or tetrachlorophenol (Luthe et al. 1995; Luthe 1996). Even the trace quantities of PCP in wood or pulp may be a source of chlorinated dioxins in effluents and final products. In the last decade, an increasing body of evidence has associated non- 
dioxin classes of chemicals, such as defoaming agents, from the manufacturing process that contain dioxin precursors (Munkittrick et al., 1998; Hewitt et al. 2006).

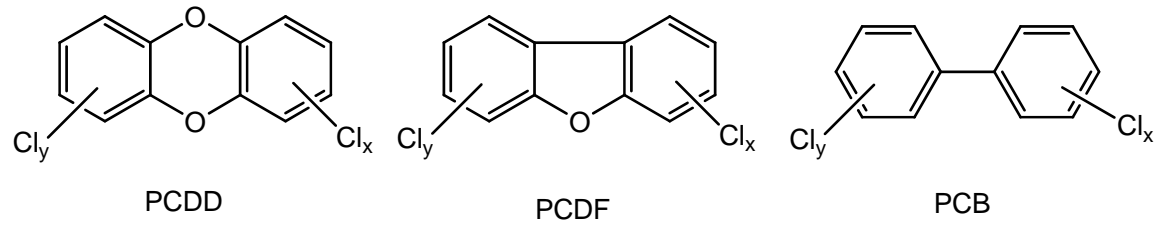

Fig. 2 Formulas of polychlorinated dibenzo-p-dioxins (PCDDs), polychlorinated dibenzofurans (PCDFs) and polychlorinated biphenyls (PCBs)

Polychlorinated biphenyls have been produced commercially from 1920s by direct chlorination of biphenyl mixtures of congeners (Srogi 2008). These were used in e.g. coatings, inks, flame retardants and hydraulic fluids. They were banned in the 1970 s due to their persistence in the environment. However, they may still be in use in closed systems, such as capacitors and transformers.

In the late 1980s, aquatic discharges from the pulp and paper industry became an area of interest as dioxins and furans were found in effluents (Kringstad and Lindstrom, 1984). Results provided some of the first evidence that effluents from pulp mills were capable of inducing chronic responses on fish reproduction even at very low concentrations (Hewitt et al. 2006). The pulp and paper mill effluents often contain dioxins which are dominated by the octachlorinated dioxin (Luthe 1996).

Even though dioxins and furans have low solubility in water, they have been found in aquatic environment mainly from atmospheric deposition but also from sewage treatment plants (Kim et al. 2002). Dioxins can be removed by e.g. coagulation, sedimentation and filtration (Srogi 2008). Most dioxin congeners can be removed from raw water during water purification process ( $87 \%$ removal efficiency). However, due to chlorination, their amount may increase during treatment processes. Therefore, effective methods for their removal from water are still needed (Lee et al. 2009). Advanced oxidation processes (AOPs) are methods based on the generation of intermediate radicals (e.g. hydroxyl radical) that are applied to degrade organic compounds (Pera-Titus et al. 2004). Methods, such as photolysis, photocatalysis and Fenton oxidation, have been studied for purposes of wastewater treatment. Especially, photolysis based on sun light radiation degrades dioxins and furans effectively (Niu et al. 2003).

\section{Extractives}

Wood extractives commonly include terpenes, phenolic substances, aliphatic carboxylic acids and alcohols and also multiple compounds with small molecular weight (Holmbom 1999; Back and Ekman 2000). The term extractive comes from the fact that they are lipophilic substances which can be extracted with neutral organic solvents, such as dichloromethane, methanol, diethyl ether, acetone and ethanol (Ekman and Holmbom 1989; Valto et al. 2012). Water-insoluble lipophilic extractives are also called wood resin or pitch and comprise of free fatty acids, resin acids, waxes, fatty alcohols, steryl esters, sterols, glyserides, ketones and other oxygen-containing compounds. The content and composition of wood extractives vary depending on the wood species, parts of tree (e.g. heartwood, sapwood), wood age, growth conditions and environmental factors (Hillis 1971; Alén 2000). For example, resin acids occur only in softwoods (Back and Ekman 2000). In 
addition, trees in warm climates produce higher amount of saturated fatty acids and show less seasonal variability.

Extractives are led to the paper mill with the pulp and water (Holmbom 1999). As the water circulations are more closed, the concentrations of dissolved and colloidal substances increase. Closure of water circulation induces challenges due to the build-up of harmful substances, such as fatty and resin acids which are the main cause of process problems including lower pulp quality, foaming, odor and effluent toxicity (Sitholé 2007; Valto et al. 2012). For example, waxes, di- and triglyserides, fats and sterols are not saponifiable and can cause disturbance during the paper making process as they remain in pulp (Rigol et al. 2004). The pitch problems can be controlled e.g. by wood seasoning or by adding tall oil containing resin and fatty acids leading to improved deresination. In that case, fatty and resin acids are bound by fatty and resin acid soaps to the pulped fibers by adding complex-forming additives which form pitch droplets onto the fiber surface (Leiviskä and Rämö 2008).

A large part of wood extractives are removed by the activated sludge treatment during which the extractives are degraded, transformed into other compounds or adsorbed by the sludge. If the biological treatment does not work properly continuously, toxic breakthroughs can occur (Leiviskä and Rämö 2008). The rest of the extractives are led to receiving waters and sediments. Emissions to water include oxygen-consuming organic substances which cause anoxia to aquatic organisms (Rigol et al. 2003a). Emissions of dissolved and colloidal substances need to be strictly controlled because these substances may cause serious ecological and toxicological effects in the receiving aquatic environments.

Wood extractives may cause harmful effects on biota (Ali and Sreekrishnan 2001; Ratia et al. 2013). The most abundant plant sterols in trees are $\beta$-sitosterol, stigmastanol, campesterol and stigmasterol (Ayebo et al. 2006). For instance, wood sterols may cause hormonal disruptions in fish because $\beta$-sitosterol and stigmasterol are able to bind to the estrogen receptor and disrupt the reproductive functions (Trembley and van der Kraak 1999). Wood sterols are highly hydrophobic and are easily adsorbed to the sediment which poses a risk to bottom feeding fish. Wood extractives have been found also from the sediments downstream from pulp and paper mills (Rämänen et al. 2010).

Previously contaminated sediments may act as source of contaminants (Ratia et al. 2013). The amount of organic material in sediment is a critical factor when considering the bioavailability of contaminants and its ability to adsorb and desorb organic material (Rämänen et al. 2010). In addition, pollutants can be released to the water due to sediment erosion which can be increased by flooding (Hollert et al. 2007). For example, in Nordic countries flooding occurs every spring due to snow melting. Also the vertical turnover of water twice a year in boreal lakes probably churns the upper sediment layer. Wood extractives from pulp and paper production can be transported over $30 \mathrm{~km}$ from the source (Rämänen et al. 2010).

\section{Fatty acids}

Fats and waxes can be defined as esters of carboxylic or fatty acids with glycerol or alcohols other than glycerol (Ali and Sreekrishnan 2001). Unsaturated fatty acids (16-C, 18-C) include acids, such as oleic acids, linoleic acid and linolenic acid. The amount of fats in dry wood varies between $0.3-0.4 \%$. The amount of fatty acids is larger in the heartwood than the sapwood. There are some free fatty acids and alcohols among extractives but the major part has reacted with glycerol (Fengel and Wegener 1989). Waxes and fats can be 
extracted from wood by organic solvents, such as diethyl ether and acetone. More than 20 different saturated or unsaturated fatty acids have been isolated from softwoods.

Fatty acids and terpenes are removed quickly during the chemical pulping (Latorre et al. 2005). Organic fatty acid esters and waxes are hydrolyzed almost completely during pulping i.e. saponified. The soaps disperse other lipophilic compounds effectively and help to remove the resin from pulp. On the other hand, unsaturated compounds, such as fatty acids, resin acids and polyterpenoids form isomers and may polymerize. Generally, more unsaturated fatty acids are formed during the hard wood pulping than during soft wood pulping (Back and Ekman 2000). The removal of extractives is more difficult in case of hard wood due to smaller fiber pores compared to soft wood fibers.

The unsaturated fatty acids are one of the groups causing toxicity e.g. to fish, especially salmonoids (Voss and Rapsomatiotis 1985). Long chain fatty acids (LCFA) inhibit methanogenic bacteria, in particular the acotoclastic bacteria, which makes the anaerobic treatment of wastewaters troublesome (Ali and Sreekrishnan 2001). Long chain fatty acids cause a lag period in methane production from acetate and a synthetic substrate $n$-butyrate (Hanaki 1981). However, fatty acids can be degraded anaerobically if their concentrations are kept low to avoid them causing significant inhibition to anaerobic bacteria.

\section{Resin acids}

Resin acids are hydrophobic, non-volatile, unsaturated, tricyclic, diterpenic carboxylic acids commonly found in tree bark and wood of conifers (McMartin et al. 2002; Rigol et al. 2003a). Concentrations of resin acids may be up to several hundred ppm and twice as high in conifers compared to deciduous trees (Werker and Hall 1999b; Ali and Sreekrishnan 2001). For example, pine contains about 12 times more resin acids compared to birch. Resin acids employ as natural antimicrobial defense in trees. They are formed from three basic groups of tricyclic diterpenes present in the resin of tree: abietane, pimarane and isopimarane. Derivatives of abietane (e.g. abietic and dehydroabietic acids) have an isopropyl substituent at $\mathrm{C} 13$ but derivatives of pimaranes and isopimaric acids have a vinyl and a methyl group in the C13 position (Fig. 3) (McMartin et al. 2002; Rigol et al. 2003a). The aromatic ring in the dehydroabietic acid structure makes it stable. Resin acids in pulp and paper effluents include e.g. abietic acid, neoabietic acid, dehydroabietic acid, pimaric acid, isopimaric acid, palustic acid, levopimaric acid and sandaracopimaric acid (Ali and Sreekrishnan 2001; McMartin et al. 2002).

Palustic, abietic, neoabietic and levopimaric acids have conjugated dienes and facilitate isomerization (Rigol et al. 2003a). On the contrary, pimaric, sandaracopimaric and isopimaric acids do not have conjugated double bonds and cannot undergo isomerization. Abietic acid is the most stable compared to other resin acids. On the other hand, levopimaric acid is the most labile and is easily transformed to abietic and dehydroabietic acids (Dethlefs and Stan 1996). Therefore, white waters and effluents contain mainly dehydroabietic, abietic, pimaric and isopimaric acids.

The composition of resin varies between wood species, location and age of wood (Alén 2000; Valto et al. 2012). The resin can be classified as pathological resin which protects the wood against biological damage or physiological resin which is the nutrient source of wood. The components of resin can be again divided into saponifiable and nonsaponifiable compounds. Due to wide variety of resin compounds, their properties cannot be unambiguously listed. However, there are common characteristics. For example, in 
acidic conditions all extractives are in colloidal form (Raymond et al. 1998). Colloidal particles are $0.2-2 \mu \mathrm{m}$ in size, negatively charged and easily form agglomerates.

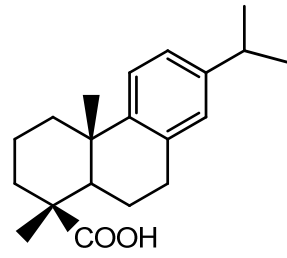

DhA

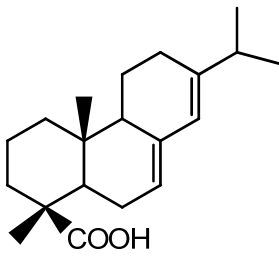

$\mathrm{AbA}$

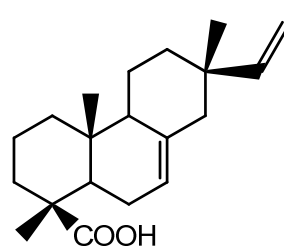

IpA

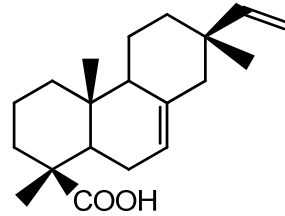

PA

Fig. 3 Examples of abietane (dehydroabietic acid, DhA; abietic acid, AbA), isopimarane (isopimaric acid, IpA) and pimarane (pimaric acid, PA) molecules

The fate of contaminants in wastewater is influenced by their hydrophobicity and solubility (Werker and Hall 1999b). Due to their hydrophobic nature, resin acids have a relatively low solubility in aqueous systems (Peng and Roberts 2000a). Dehydroabietic acid is the most soluble in water $(5.1 \mathrm{mg} / \mathrm{L})$ which is about twice as much as the other resin acids. The solubility of resin acid varies according to its acid ionization and is in the range 3-6 mg/L. At $\mathrm{pH} 6.0$ resin acids are quite hydrophobic and weakly soluble in water $(\sim 5 \mathrm{mg} / \mathrm{L})$ but at $\mathrm{pH} 8.0$ they become less hydrophobic and more soluble in water $(200 \mathrm{~g} / \mathrm{L})$. Therefore, the aquatic toxicity of resin acids decreases with $\mathrm{pH}$ (Zanella 1983). Generally, alkaline conditions promote a removal of greater extent due to $\mathrm{pH}$-dependent changes of the contaminant bioavailability.

Resin acids may be hazardous to animals, humans and plants (McMartin et al. 2002). They are hydrophobic and toxic to fish at concentration of $200-800 \mu \mathrm{g} / \mathrm{L}$ (Ali and Sreekrishnan 2001). For example, 96-h lethal concentration for $50 \%$ of population $\left(\mathrm{LC}_{50}\right)$ toxicity levels for salmon and rainbow trout range between $0.4-1.7 \mathrm{mg} / \mathrm{L}$. In addition, it is believed that resin acids cause the main toxicity effect of pulp and paper effluents (Ali and Sreekrishnan 2001). The wastewater toxicity strongly depends on $\mathrm{pH}$ and solubility. Generally, resin acids have higher toxicity at low $\mathrm{pH}$ than their dissociated counterparts at high $\mathrm{pH}$ as their water solubility increases. Resin acids are also toxic to fish and invertebrates and cause impaired liver functions (Ratia et al. 2013). In addition, their anaerobic biotransformation product retene can be bioavailable to animals living in sediments causing reduced growth and mortality on early live of fish (Vehniäinen et al. 2003).

Resin acids accumulate in liver and bile of fish and may cause disruptions in liver and red cells, such as accelerated decomposition of red cells and disturbed iron metabolism (Kostamo et al. 2004). In addition, they decrease the levels of reproductive hormones and may interfere with the cell production (Christianson-Heiska et al. 2008). For example, wood sterols resemble the steroid-type group of hormones and can disturb the development and reproduction of organism (Mattson et al. 2001). However, the exact mechanism of resin acids causing toxicity towards aquatic organisms is still unknown. The levels of these compounds are small and have not been shown to disturb hormone balance of aquatic organisms. However, even the smallest amounts of resin acids accumulated in the liver and bile of organisms can cause disturbances in the long run (Rissanen et al. 2003). 


\section{Betulinol}

Betulinol (lup-20(29)-ene-3ß,28-diol, also referred as betulin, Fig. 4) is a lipophilic compound, poorly soluble in water and structurally resembles sitosterols (Mellanen et al. 1996; Alakurtti et al. 2006). Betulinol is a triterpene alcohol present in high amounts in the outer bark layer of birch and the most common extractive in birch (Alakurtti et al. 2006; Ratia et al. 2013). Betulinol is found up to $30 \%$ of dry weight in the bark of birch but small amounts of betulinol can be found from other sources (Alakurtti et al. 2006). It can be isolated from bark by extraction with boiling hydrocarbon solvents or with water azeotropes of alchols (Eckerman and Ekman 1985).
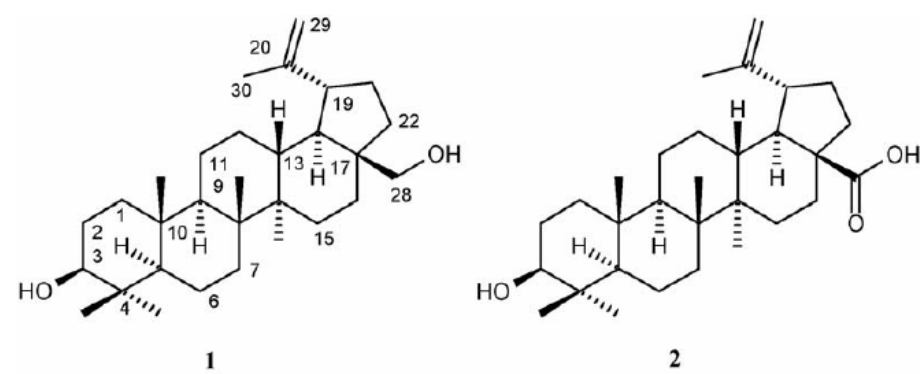

Fig. 4 Betulinol (1) and betulinic acid (2)

The birch triterpenes, including betulinol, have known antiviral, antimicrobial and hepatoprotective pharmacological activities (Eiznhamer and $\mathrm{Xu}$ 2004). Betulinol is known to inhibit bacterial growth (Salina et al. 2010). It is potentially an important raw material for polymers and biologically active compounds. Betulinol can be easily converted to betulinic acid (Fig. 4). Both are known to have anti-inflammatory, antimalarial, anti-cancer and antifungal activities (Alakurtti et al. 2006; Moghaddam et al. 2012). Betulinic acid is sytotoxic to several tumor cells, such as breast, colon and lung cancer cells by inducing cell apoptosis (Pisha et al. 1995; Alakurtti et al. 2006). In addition, betulinic acid, as well as dihydrobetulinic acid, inhibits HIV activity (Fujioka et al. 1994). Generally, the toxicity of triterpenes is relatively low (Jäger et al. 2008). Betulinic acid is non-toxic up to $500 \mathrm{mg} / \mathrm{kg}$ body weight in mice (Pisha et al. 1995) and, for example, $600 \mathrm{mg} / \mathrm{kg}$ body weight in rats and mice dose is well tolerated (Astudillo et al. 2002).

Betulinol is a potential estrogen (Mellanen et al. 1996). Estrogenic compounds derived from wood can potentially cause reproductive dysfunction in fish when released into aquatic environment via pulp mill effluents (Christianson-Heiska et al. 2008). There are some evidence suggesting that the wood extractives, including betulinol, may possess different endocrine activities associated with developmental or maturational stages of fish and exposure time (Christianson-Heiska et al. 2008). Betulinol, among other wood extractives, has been shown to stimulate the growth of fish, such as rainbow trout (Oncorhyncus mykiss) exposed to pulp mill effluents (Mattson et al. 2001). For example, $10 \mathrm{mg} / \mathrm{l}$ exposure to phytosterols, accumulated via the mother, already has an effect on fish larvae, stimulating their growth. According to Mellanen et al. (1996), the estrogenic potency of betulinol is higher than that of $\beta$-sitosterol and $\beta$-sitostanol but lower than $17 \beta$ estradiol.

Only a minor part of extractives, including sterols are adsorbed to the sludge at the primary clarifier and the activated sludge treatment is the main treatment for their removal (Kostamo et al. 2004). Sterols are more likely to occur in the water phase than in particles in wastewater treatment. After the primary treatment, sterols are mostly adsorbed to the 
primary sludge but some is already degraded, probably due to some microbial activity. However, during biological treatment, sterols are more likely to transform than degrade.

High amounts of $\beta$-sitosterol and betulinol are distributed with the effluents in the upper sediment layer in lakes downstream from effluent source (Meriläinen et al. 2006; Ratia et al. 2013). Additionally betulinol and wood sterols can be desorbed from sediments to water. Compounds in the sediment may be bioavailable for bottom feeding fish (Lahdelma and Oikari 2006). The extent of desorption may depend on their concentration in the sediment. In case of extensive erosion, high amounts of betulinol and wood sterols may be dissolved and cause toxic effects in aquatic organisms (Rämänen et al. 2010).

\section{BIOCIDES}

Biocides are widely used to combat microbial, fungal and algal growth (Latorre et al. 2005). The type of biocide is selected based on the point of application, target microbe and chemical compatibility of the process. In papermaking process, there are aerobic and anaerobic bacteria, fungi and yeast. Aerobic bacteria include Acromonas and Escheria coli while fungi include Aspergillus and Trichoderma. Bacteria, such as Pseudomonas are commonly found in the process water.

Biocides can be divided into oxidizing agents, such as chlorine dioxide, hydrogen peroxide and highly toxic organic chemicals including thiocyanates, isothiazolins, cyanobutane and bromo compounds (Latorre et al. 2005). They can also be classified based on their chemical structures or their mode of action, such as membrane active biocides, permeabilizers, cell wall inhibitors, cytotoxic agents and genotoxic agents. Oxidizing biocides are fast-killing and relatively cost-effective. The oxidants either kill the bacteria or weaken the cell walls which make them more susceptible to other classes of biocides (Cserjesi and Johnson 1982). However, non-oxidizing agents are more effective and both are often used together. The oxidants, such as chlorine and peroxides work via radicalmediated reactions oxidizing organic material (Schaechter and Lederberg 2004). The electrophilic agents include inorganic ions (e.g. silver, copper, mercury) and organic biocides (e.g. formaldehyde, isothiazolones). Other biocides react covalently with cellular nucleophiles and inactivate enzymes (Slawson et al. 1992). Cationic membrane active biocides (e.g. chlorhexidine and quaternary ammonium compounds) destabilize membranes and cause rapid cell lysis.

Biocides pose a risk of negative effects in the receiving waters (Latorre et al. 2005; Oller et al. 2011). Their propagation is very easy in the environment due to their high solubility. Most biocides are resistant to chemical and photochemical degradation under typical environmental conditions. In addition to possible chronic effects, many of them are carcinogenic, neurotoxic and have effects on the reproduction and cell development, especially in the early stages of life (Blair et al. 1993; Hileman 1994). Biocides can be found in surface waters from streams and ditches adjacent to agricultural fields and rivers, lakes and reservoirs (Liess and Von der Ohe 2005). Part of the contamination results from non-agricultural uses of biocides (Skark et al. 2004). Also diffuse contributions of biocides to water are important including spray drift, surface runoff and leaching. Biocide contamination in wastewater from these sources may be as high as $500 \mathrm{mg} / \mathrm{L}$ which have to be removed before releasing to natural water bodies. 


\section{Biocides in pulp and paper industry}

Slime formation on the surfaces of manufacturing equipment is unfavorable and may lead to production breakdown, corrosion, reduction of product quality and bad odors (Pereira et al. 2001). Bacterial growth in biofilms may produce metabolites, such as organic or inorganic acids which promote corrosion of the steel surface (Kolari 2003). Biocides are the main practice in eliminating unwanted microbial growth. However, more restricted environmental regulations have created the need to develop less toxic alternatives for biofilm control. Biocide is chosen based on knowledge of process conditions and types of microorganisms forming the biofilm (Cloete et al. 1998). For example, carbamate-based biocide (e.g. sodium dimethyl dithiocarbamate and disodium ethylene bisthiocarbamate) and glutaraldehyde are usual biocides to control biofilm formation in pulp and paper mills. Other biocides used in paper making processes include e.g. halogenated hydantoin, 2-bromo-2-nitropropane-1,3-diol and n-octyl-isothiazolin-3-one. The types used in the coating processes differ from those in the other pulp and paper making processes. In coating, longer lasting protection is needed. Biocides, often termed preservatives, include e.g. thione, glutaraldehyde and 1,2-benzo-isothiazolin-3-one. Additionally, surfactants, such as alkyl sulphosuccinates, and other film forming inhibitors can be used.

Repeated treatments by certain biocides can lead to resistant strains of microorganisms (Pereira et al. 2001). Closed water circulations and neutral or basic conditions have made the control of microorganisms even more challenging. Previously, the most important biocides in the papermaking were chlorine and copper sulfate (Sanborn 1965). Later in the 1950s and 1960s, organic mercury compounds, such as phenylmercuric acetate and ethylmercury salts were used and often in combination with chlorophenates (Appling et al. 1955; Sanborn 1965). However, these compounds were prohibited because of their adverse environmental effects. In addition, organic tin compounds including distannoxane, bis(tri- $n$-butyltin) oxide with quaternary ammonium compounds, were used despite being very toxic to aquatic life (McCoy 1980).

A fraction of biocides will degrade biologically or chemically but some will remain in aqueous phase and the rest will be present in the effluent or solid material (Latorre et al. 2005). In addition, some biocides can be fiber retentive and accumulate in the final paper product due to their physicochemical properties (Abrantes et al. 1998). Biological methods are preferred for treatment of biocides containing effluents. However, toxic compounds inactivate degrading microorganisms (Latorre et al. 2005; Oller et al. 2011). Therefore, a useful approach is to partially pre-treat the toxic waste by oxidation. Oxidation treatments include photochemical processes $\left(\mathrm{UV} / \mathrm{O}_{3}, \mathrm{UV} / \mathrm{H}_{2} \mathrm{O}_{2}\right)$, (Andreozzi et al. 2003; ChelmeAyala et al. 2010) photocatalysis $\left(\mathrm{TiO}_{2} / \mathrm{UV}\right.$, Fenton, photo-Fento) (Kitsiou et al. 2009) and chemical oxidation $\left(\mathrm{O}_{3}, \mathrm{O}_{3} / \mathrm{H}_{2} \mathrm{O}_{2}, \mathrm{H}_{2} \mathrm{O}_{2} / \mathrm{Fe}^{2+}\right)$ (Benitez et al. 2001).

\section{Benzothiazoles}

Benzothiazoles are manufactured for industrial applications including fungicides and algicides and can enter the environment by water and air emissions (Nawrocki et al. 2005). For example, 2-(thiocyanomethylthio)benzothiazole (TCMTB, Fig. 5) is a benzothiazole derivative specifically developed for use as a biocide and commonly used in pulp and paper industry (Agueira et al. 2000). TCMTB has been used for 20 years globally as an alternative to chlorophenol compounds. In addition, TCMTB is used as a substitute for tri- $n$-butyltin in antifouling paints. Chlorophenol compounds have been banned because of their toxicity, persistence, occupational impacts and hazardous impurities. 

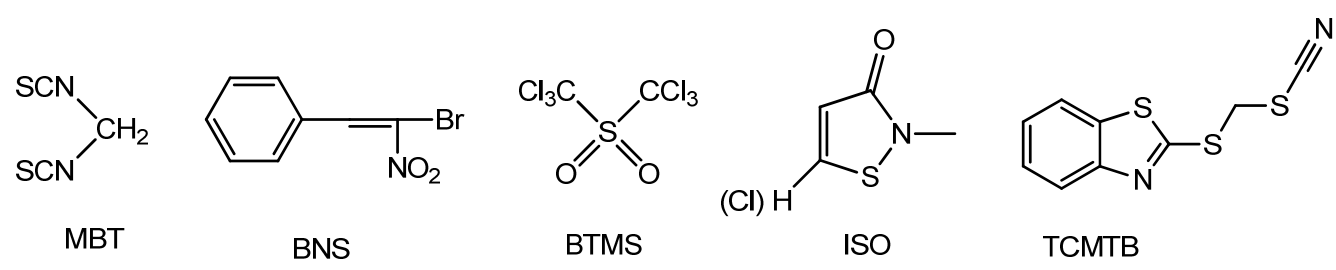

Fig. 5 Benzothiazole biocide compounds: methylene-bis-thiocyanate (MTB), $\beta$-bromo- $\beta$ nitrostyrene (BNS), bis-trichloromethyl-sulfone (BTMS), 2-methyl-isothiazolin-3one/ 5-bromo-2-methyl-4-isothiazolin-3-one (ISO), 2-(thiocyanomethylthio)benzothiazole (TCMTB)

TCMTB does not naturally occur in nature and its sources are of anthropogenic origin. However, its derivatives 2-mercaptobenzothiazole (2-MBT), 2-(methylthio) benzothiazole (MTBT), benzothiazole (BT), and 2-hydroxybenzothiazole (HOBT) can be produced naturally by few organisms (De Wever and Verachtert 1997). TCMTB degrades rapidly in the environment by e.g. hydrolysis or photolysis. At $\mathrm{pH} 5$ TCMTB is stable but it is slowly hydrolyzed at $\mathrm{pH} 7$ and at $\mathrm{pH} 9$ the hydrolysis proceeds rapidly (Meding et al. 1993). The breakdown results mainly from photolysis and requires less than 1 day for $50 \%$ degradation in full sun light. Full degradation proceeds between less than 24 hours to 9 days (Brownlee et al. 1992).

TCMTB is nonvolatile and has a low vapor pressure. Its mineralization is unlikely because the compound breaks down into relatively stable product molecules (Nawrocki et al. 2005). 2-MBT, transformation product of TCMTB, is photolyzed in water to BT and HOBT. It may undergo biomethylation and form MTBT which is resistant to photolysis. In aquatic solution with chlorine, it can oxidize to HOBT. The degradation products MTBT, BT and HOBT may be persistent in nature and occur in high concentrations. TCMTB and its transformation products are acutely toxic to algae, fish and daphnia (Kruzynski and Birtwell 1994). Benzothiazole compounds are not entirely removed from wastewater during common anaerobic or aerobic treatment processes (Reemtsma et al. 1995). TCMTB is several orders of magnitude more toxic than its degradation products in both acute and chronic exposures and toxic effects can be observed even at ppm concentrations (Nawrocki et al. 2005). The effective concentration, $\mathrm{EC}_{50}$ for TCMTB is $15.3 \mu \mathrm{g} / \mathrm{L}$ and $4.19 \mathrm{mg} / \mathrm{L}$ for 2-MBT (Hanssen and Henderson 1991). The more stable MTBT has been shown to be less toxic with $\mathrm{EC}_{50} 12.7 \mathrm{mg} / \mathrm{L}$.

\section{ANALYSES}

The compounds in pulp and paper mill process waters and effluents can be analyzed by variety of methods (Wilhelm et al. 1999; Valto et al. 2012). Even though there are standardized methods, the methods applied vary from mill to mill. For example, resin and fatty acids can be analyzed by chromatographic methods, such as gas chromatography (GC), liquid chromatography (LC), thin layer chromatography (TLC) and gel permeation chromatography (GPC) (Holmbom and Stenius 2000; Fardim et al. 2005). Detectors include e.g. flame ionization detector (FID) and MS. In addition, infrared spectroscopy (IR) and nuclear magnetic resonance spectroscopy (NMR) have been used for the analysis of pitch but also e.g. gravimetric, titrimetric and photometric methods can be used for the detection of compounds in pulp and paper mill effluents. 


\section{Extraction}

The enrichment of the sample is a crucial step because the concentrations of pollutants are typically low. Traditionally, liquid-liquid extraction (LLE) is a common procedure and has been used to extract e.g. resin and fatty acids (Koistinen et al. 1998). Extraction can be performed with dichloromethane (DCM), methyl tert-butyl ether (MTBE), trichloromethane (TCM), diethyl ether or with a combination of those. For example, MTBE extracts both lipophilic and hydrophilic groups. Generally, two extractions are sufficient, but three provides higher yields of hydrophilic components, such as lignans (Örså and Holmbom 1994). Extraction is commonly performed under neutral or alkaline conditions due to $\mathrm{pH}$ of white water $(\mathrm{pH}$ 6-8) even though acidic conditions decrease microbial growth during sample storage and reduce formation of emulsion (Örså and Holmbom 1994; Rigol et al. 2003a). In addition, protonation of carboxylic group decreases the hydrophilic character of resin acids and improves the efficiency of extraction. On the other hand, extraction in alkaline conditions minimizes isomerization of resin acids and increases extractability.

Solid-phase extraction (SPE) with reversed-phase or cross-linked polystyrene sorbents have advantages over solvent extraction methods (Rigol et al. 2003a). For example, samples with large volumes and small concentrations can be collected. However, SPE can handle only the soluble fraction of the sample which may need filtering (Mosbye et al. 2000). This may cause losses of analytes adsorbed onto particulate matter. Extraction recoveries of resin acids are generally over $90 \%$ with both LLE and SPE methods but the reproducibility is better with SPE. For example, SPE is successfully applied in analysis of long-chain fatty acids and resin acids (Pan and Pawliszyn 1997).

Traditional offline SPE is increasingly replaced with online SPE or with largevolume injection (LVI) prior to LC (Huntscha et al. 2012). Online SPE reduces the time required for the extraction. On the other hand, LVI is performed without prior enrichment. Several microliters up to few milliliters of filtrated or centrifuged sample is injected directly into the chromatographic column. The online-SPE instrumental set-up comprises a dispenser syringe, a sample loop, three LC pumps, two six-port valves, and an online extraction cartridge. The equipment is suitable for variety of analytes, such as biocides and pesticides in groundwater, surface water, and wastewater.

\section{Gas chromatography}

Traditionally, resin acids have been analyzed by GC coupled with FID (Latorre et al. 2003; 2005). However, the analysis of complex matrices is difficult and MS detector is often more useful. Derivatization of the analyte is needed either by using methylation agents (e.g. diazomethane, bis(trimethylsilyl)trifluoroacetamide (BSTFA) combined with trimethyl-chlorosilane or pentfluorobenzyl (PFB) esters in case of resin acids). Methylation is a common derivatization method but strong methylation agents are required because of the sterically hindered carboxylic group of resin acids (Rigol et al. 2003a). Because strong methylation agents present severe health hazards, other methylation agents, such as methyl8 ( $N, N$-dimethylformamide dimethyl acetal), have been introduced (Peng and Roberts 2000b). Alternatively, trimethylsilyl esters can be synthesized by the use of BSTFA with trimethylchlorosilane. Trimethylsilyl (TMS) esters of resin acids are susceptible to hydrolysis and thus have limited stability. The technique is easy and highly sensitivity but often needs confirmatory analysis, for example, MS detection. Unfortunately, the half-life of derivatized extract is commonly very short (12 hours) and the derivatization may need re-performing in case of fail of injection sequence. 
Internal standard is often needed for the quantification (Rigol et al. 2003a). For example, margaric acid $\left(\mathrm{C}_{17} \mathrm{H}_{34} \mathrm{O}_{2}\right)$ is commonly used because it does not coelute with resin or fatty acids and is unusually found in water samples. Heneicosanoic $\left(\mathrm{C}_{21} \mathrm{H}_{42} \mathrm{O}_{2}\right)$ and tricosanoic $\left(\mathrm{C}_{23} \mathrm{H}_{46} \mathrm{O}_{2}\right)$ acids are other alternatives. Many resin acids have similar molecular structures which is why their separation as free acids or derivatives has not been an easy task. However, high resolution of short $(5-7 \mathrm{~m})$ capillary columns with a film of non-polar stationary phase provides separation of extractives (e.g. fatty acids, resin acids, lignans) (Örså and Holmbom 1994). If more accurate information about individual resin acid is required, the analysis needs to be performed with a longer column $(15-30 \mathrm{~m})$.

Both GC-MS and LC-MS methods show good linearity and precision in the analysis of resin and fatty acids (Latorre et al. 2003). Additionally, similar results of concentration levels can be obtained with both methods. The GC-MS provides more exhaustive analysis of single resin acids but is more time-consuming and requires more sample manipulation caused by the preparation of derivatives. GC coupled with FID, ECD or MS has been widely used for the analysis of resin acids in effluents. Derivatization is often recommended to improve separation even though direct analysis has also been performed. On the other hand, LC-MS provides less information about the exact resin acid composition but is a suitable method for routine monitoring of fatty acids and total concentration of resin acids with minimal sample preparation.

FID is the most used detection method because it is sensitive, reliable and gives a wide linear range (Rigol et al. 2003a). MS permits also unequivocal identification of different compounds in complex mixtures. Electron impact ionization gives a complicated spectrum and many peaks below m/z 150. All in all, GC-FID and GC-MS are suitable analytical tools for analysis of resin acids in complex mixtures. The challenges include long separation times ( $\sim 60 \mathrm{~min}$.), requirement of derivatization and low stability of derivatives. However, detection limits of $\mathrm{ng} / \mathrm{L}$ of some resin acids have been achieved with MS detection (Latorre et al. 2003).

\section{Liquid chromatography}

The analysis of polar and medium polar contaminants is usually performed by LC coupled to MS or tandem MS (Huntscha et al. 2012). LC has been used for the quantitative analysis of resin acid mixtures and for the determination of total resin acids in water (Rigol et al. 2003a). The main difficulties include separation of various resin acid isomers with a $\mathrm{C} 8$ or $\mathrm{C} 18$ column because all resin acids have similar interactions with the column. In case of UV detection, the lack of chromophores makes the detection difficult, especially in case of non-conjugated resin acids. LC-MS method can be applied without derivatization and with direct sample introduction (McMartin et al. 2002; Rigol et al. 2003b).

For example, resin acids in natural water samples have also been quantified with LC coupled to negative ion electrospray (ESI)-MS (McMartin et al. 2002). Generally, LC methods can be performed with using either ESI or atmospheric pressure chemical ionization (APCI). By this technique, the extract can be directly injected in a reverse phase column (Rigol et al. 2003b; Latorre et al. 2005). The method requires minimal sample preparation with no extraction or derivatization due to low volatility of analytes (Petrović et al. 2001). The LC-ESI-MS method is rapid and highly sensitive for the quantitative analysis of spiked natural waters. However, structural resin isomers (AbA, IpA and PA) cannot be separated and thus the method is recommended only if individual isomeric resins do not need separation. 
MS detection of resin acids can be performed with ESI or APCI interfaces under negative ion conditions producing [M-H] ${ }^{-}$ions (Rigol et al. 2003b). However, chlorinated and non-chlorinated dehydroabietic acids cannot be separated because both show ions with the same $\mathrm{m} / \mathrm{z}$ value. The level of detection varies from $0.3-3 \mu \mathrm{g} / \mathrm{L}$ which is higher than those obtained by GC. However, the concentrations of resin acids in effluents are often high (even $\mathrm{mg} / \mathrm{L}$ ) and the same sensitivity of other toxicants is not required. Only minimum sample preparation is required with LC methods compared to GC which makes them more suitable for the routine analyses of process waters and effluents. For example, a rapid APCI-MS method with online enrichment and selected ion monitoring (SIM) technique is a potential method for monitoring resin acids in process waters (Valto et al. 2008; 2009). However, the method provides no accurate concentrations of individual compounds.

MS detection with ESI requires lower temperature for ionization than the other ionization methods, and thus can be used for thermally unstable compounds (Santa et al. 2007). The decrease in the noise level by MS/MS detection also enables sensitive detection of the targeted compounds. However, all compounds are not suitable for LC/ESI-MS/MS analysis, since the ionization efficiencies of some compounds are extremely low and such compounds cannot be sensitively detected. Commonly, the aim is to enhance the ESI response but not to generate a particular product ion by CID. However, fatty acids, e.g. octanoic acid, can be derivatized with benzofuran reagents, such as DAABD-AE \{4-[2-(N,N-dimethylamino)-ethylaminosulfonyl]-7-(2-amino-ethylamino)-2,1,3-benzoxadiazole $\},$ DAABD-PZ \{4-[2-(N,N-dimethylamino) ethyl-aminosulfonyl]-7-N-piperazino2,1,3-benzoxadiazole $\}$ or DAABD-APy $\{4-[2-(\mathrm{N}, \mathrm{N}-$ dimethylamino)ethyl-aminosulfonyl]7-(3-aminopyrrolidin-1-yl)-2,1,3-benzo-xadiazole $\}$ to enhance their ionization and then analyzed with LC-ESI-MS/MS (Santa et al. 2007). In addition, fatty acids in human tissue samples can be analyzed by LC-ESI-MS/MS (Chen et al. 2014). Even low picogram concentrations of each fatty acid can be determined.

Biocides are generally analyzed from pulp and paper mill waters by LC techniques because paper mill biocides are commonly polar and highly soluble compounds (Latorre et al. 2005). For example, LC-UV detector is suitable for detection of TCMTB and chlorophenols (Daniels and Swan 1987) and LC-ESI-MS in the positive ion mode can be employed for detection of TCMTB and 2,2-dibromo-3-nitrilopropionamide (DBNPA) in effluent waters at $\mu \mathrm{g} / \mathrm{L}$ concentrations (Rigol et al. 2002). In addition, biocides in various water and effluent samples can be extracted with SPE and analyzed by LC-MS/MS (Chen et al. 2012). In case of solid samples, ultrasonic extraction is a suitable technique. Examples of different methods of analyses and analytes are listed in Table 1. 
Table 1 Examples of groups of compounds in pulp and paper mill wastewaters and methods of their analysis

\begin{tabular}{|l|l|l|l|}
\hline Compounds & Method & Matrix & Reference \\
\hline Resin acids & LC-MS & Natural water & McMartin et al. 2002 \\
\hline $\begin{array}{l}\text { Resin acids, fatty } \\
\text { acids }\end{array}$ & -/LLE-LC-MS & White water, effluents & Rigol et al. 2003b \\
\hline $\begin{array}{l}\text { Resin acids, fatty } \\
\text { acids }\end{array}$ & LLE-(BSTFA)-GC-MS & $\begin{array}{l}\text { Pulp and paper mill } \\
\text { process waters }\end{array}$ & Latorre et al. 2003 \\
\hline $\begin{array}{l}\text { Resin acids, fatty } \\
\text { acids }\end{array}$ & Online APCI-MS & $\begin{array}{l}\text { TMP grinding process } \\
\text { water }\end{array}$ & Valto et al. 2009 \\
\hline Fatty acids & $\begin{array}{l}\text { LC-(DAABD-AE)- } \\
\text { MS/MS }\end{array}$ & - & Santa et al. 2007 \\
\hline Fatty acids & LC-MS/MS & Mammalian tissue & Chen et al. 2014 \\
\hline $\begin{array}{l}\text { Biocides, e.g. } \\
\text { Carbendazim, } \\
\text { Diuron }\end{array}$ & Online SPE-LC-MS/MS & $\begin{array}{l}\text { River water, ground } \\
\text { water }\end{array}$ & Huntscha et al. 2012 \\
\hline $\begin{array}{l}\text { Biocides, e.g. } \\
\text { isothiazolinones }\end{array}$ & SPE-LC-MS/MS & $\begin{array}{l}\text { Municipal wastewater, } \\
\text { surface water }\end{array}$ & Chen et al. 2012 \\
\hline $\begin{array}{l}\text { Biocides, e.g. } \\
\text { isothiazolinones }\end{array}$ & $\begin{array}{l}\text { Ultrasonic extraction- } \\
\text { LC-MS/MS }\end{array}$ & Sediment, sludge, soil & Chen et al. 2012 \\
\hline Isothiazolines & $\begin{array}{l}\text { LC-MS/MS } \\
\text { GC-MS }\end{array}$ & $\begin{array}{l}\text { River water, tap water } \\
\text { River water, wastewater }\end{array}$ & $\begin{array}{l}\text { Speksnijdera et al. 2010 } \\
\text { Rafoth et al. 2007 }\end{array}$ \\
\hline $\begin{array}{l}\text { Triclosan, } \\
\text { methyl triclosan }\end{array}$ & SPE-GC-MS & $\begin{array}{l}\text { Wastewater influent, } \\
\text { effluent, river water, } \\
\text { drinking water }\end{array}$ & Kantiani et al. 2008 \\
\hline
\end{tabular}

\section{TOXICITY}

\section{Properties of toxicants}

The LMW compounds are the main cause of mutagenicity and bioaccumulation due to their hydrophobicity and ability to penetrate cell membranes (Savant et al. 2006). On the other hand, the HMW compounds are generally biologically inactive and have only a minor contribution to toxicity. However, there are indications that lignin derivatives with HMW exhibit slightly toxic potential (Pessala et al. 2010). The LMW compounds are known to bioaccumulate in the body fat of animals. The toxic effects of AOX vary from carcinogenicity and mutagenicity to acute toxicity. Because of this, several countries have established limit for AOX discharged per ton of pulp. For example, twelve European countries have set, according to PARCOM (Paris Convention for Prevention of Marine Pollution for Land Based Sources and Rivers), a general limit of $1 \mathrm{~kg}$ AOX per ton of bleached chemical pulp (Savant et al. 2006).

The high-molecular-weight fraction, comprising $80 \%$ of organic chlorine compounds, are not acutely toxic to biota but can be toxic to aquatic organisms (Naru et al. 1993). However, the LMW fraction of organic chlorine compounds is known to be toxic and mutagenic (Kingstad and Lindstrom 1984). In addition, their slow degradation and accumulation may cause long term problems and high concentrations of COD. Even though some of the compounds can degrade during the effluent treatment process, they can have high COD concentrations and cause toxic effects.

Hydrophobic toxic compounds are mostly adsorbed by the suspended particulate matter (SPM) which is found in high concentrations in industrial effluents (White et al. 
1998). SPM contains both short-living and persistent pollutants. When it accumulates in the sediment it may contribute to the exposure of aquatic organisms to toxic compounds. There are genotoxic compounds in European river SPM (Vincent-Hubert et al. 2012). The source of toxic compounds seems to be closely associated with effluents discharged to the water body.

Organisms ingesting sediment particles may accumulate high concentrations of pollutants (Saski et al. 1997). Bioconcentration factors, i.e. the ratio that results from exposure to contaminated water may be linearly predicted from $\log \mathrm{K}_{\mathrm{ow}}$ values for some chemicals. Macromolecular $(\mathrm{MW}>1000)$ chlorolignosulfonic acids have been found in sulfite pulp mill effluents and chlorothiolignins in kraft mill effluents. Kraft pulp mill effluents containing chlorine and sulfur may be bound to the same carbon skeleton. Organosulfurs, such as thiophene, dibenzothiophene and thianthrene, as well as di, tri and tetrachlorinated dimethyl sulfones have been found in pulp mill effluents but they account for much less than $1 \%$ of the extractable organic sulfur (Sinkkonen et al. 1994).

\section{Pulp and paper mill effluents}

Paper mill effluents are commonly rich in color, suspended solids, nutrients and an overall high toxicity (Rigol et al. 2004). Toxicity of pulp and paper mill effluents is caused by the chemical cocktail made of antifoams, biocides, de-inkers, surfactants but also by the wood-derived compounds, such as resin and fatty acids. These properties cause eutrophication, oxygen depletion of receiving waters and poor quality of water. Fauna living close to paper mill discharges suffer from skin diseases, changes in growth rates, delayed sexual maturation and reproduction (Södergren et al. 1988; Adams et al. 1992). Even with low concentrations (10-20 $\mu \mathrm{g} / \mathrm{l})$ reproduction and growth of fish are disrupted (Kostamo and Kukkonen 2003; Leiviskä and Rämö 2008). In addition, oxygen depletion is causing anoxia in fish and other aquatic species (Shimp et al. 1993). However, the specific compounds causing these effects are hard to establish. Even though effluent waters are treated and the emissions reduced, several families of toxicants have been found in pulp and paper mill effluents.

Several organochlorine compounds are formed during chlorine bleaching of pulp, collectively measured as AOX (Deshmukh et al. 2009). They are often highly toxic and biologically persistent (Thompson et al. 2001). The toxic effects vary from carcinogenicity and mutagenicity to acute toxicity (Savant et al. 2006). The increased awareness of the harmful effects has resulted in stringent regulations on AOX discharge limits (1 kg AOX/ton of paper). Therefore, it is essential to treat the wastewaters and remove AOX prior to discharging the effluent to the environment.

Natural products of wood, such as fatty acids, sterols and diterpen alcohols account for most (70-100 \%) of the toxicity of pulp and paper effluents (Örså and Holmblom 1994). Fatty and resin acids are toxic to aquatic organisms and even low concentrations can lead to long-term effects (Kostamo et al. 2004). For example concentration of $10 \mu \mathrm{g} / \mathrm{L}$ causes disturbed growth of fish larvae and chronic toxic effects can be seen at $20 \mu \mathrm{g} / \mathrm{L}$ (Werker and Hall 1999a). In addition, plant sterols disturb hormonal activity of many aquatic organisms because the structure of sterols resembles that of steroid hormones of vertebrate (Stahlschmidt-Allner et al. 1997; Kostamo and Kukkonen 2003). For example, the sterols have been found to have adverse effects on the development, growth and reproduction of fish (Mattson et al. 2001). 


\section{Effect of process solutions}

Process solutions, such as extended cooking and the replacement of chlorine bleaching by elemental chlorine free or total-chlorine free (TCF) bleaching has decreased the AOX load by 48-65\% reducing the formation of chlorinated compounds (Kostamo et al. 2004). It has been suggested that the toxicity of effluents is not dependent on the bleaching method (Tana and Lehtinen 1996). However, other process stages, such as debarking and cooking have an effect on the toxicity (Ahtiainen et al. 2003). Secondary wastewater treatment reduces toxicity but the effluents can still cause chronic effects on aquatic organisms (Kovacs and Voss 1992).

The chlorine based bleaching agents cause formation of dioxins and furanes, chlorinated phenolics, such as chloroguaiacols and chlorocathecols (Knuutinen et al. 1982; Zacharewski et al. 1995; Kaplin et al. 1997). The use of chlorine containing chemicals can be reduced by e.g. removing more lignin before the chlorine bleaching step, using chlorine dioxide instead of chlorine gas (ECF bleaching) or using total chlorine free (TCF) bleaching (Deshmukh et al. 2009). The anaerobic process can be considered the most economical and environmentally friendly for the treatment of AOX containing wastewaters. AOX and color of the wastewater are the most efficiently removed by combining the anaerobic and aerobic treatments because highly chlorinated compounds are more likely degraded in the anaerobic conditions (Pokhrel and Viraraghavan 2004; Savant et al. 2006).

Water circulations are being closed to reduce fresh water consumption and avoid spills of wastewaters to nearby water bodies (Rigol et al. 2004). However, the toxicity is higher in paper mills operating under closed water systems because the concentrations of compounds are increased in the circulation waters. This leads to need of additives, such as biocides and fungicides to inhibit the bacterial and fungal growth. However, the number of mills with closed water circulation has increased because of the need to reduce water consumption and to avoid spills of wastewater into the nearby water bodies.

After the establishment of wastewater treatment plants, most of the natural waters have recovered rather quickly (Ratia et al. 2012). However, morphological and structural abnormalities have been found from some of the caddisflies (Hydropsychidae) which can be associated with pollution by e.g. organochlorine compounds. Ratia et al. (2012) reported that the current discharge from the pulp and paper mills or re-suspension of contaminants from the sediment have ecotoxicological impacts on caddisflies assuming the load remains unchanged (Rämänen et al. 2010). The harmful compounds can be transported far from their source. However, it can be assumed that the increased oxygen concentration of water bodies allow the recovery.

\section{Toxicity of biocides}

When effluents show toxic properties, it is necessary to identify the chemical components causing the toxicity (Milanova and Sithole 1997). Compounds, such as wood extractives, phenols and chlorinated phenolics are often the major contributors to the effluent toxicity but the contribution of chemical additives used in pulp and paper processes have not been thoroughly investigated. Biocides are widely used in papermaking and their use is expected to increase when recycled fibers are used as raw material (Sorrelle and Belgrad 1992). The biocides are designed to be toxic to bacteria and fungi and therefore they can be toxic to fish even at low concentrations. Typically, median lethal dosages are tested by rats but no information is available about the effects on aquatic organisms.

The biocides exhibit acute toxicity to fish even at sub-ppm levels (Milanova and Sitholé 1997). B-bromo- $\beta$-nitrostyre and methylene-bis-thiocyanate degrade easily in 
aquaeous environment and are not likely to accumulate in the environment. However, if the conditions are not suitable for their degradation, the biocides cause acute toxicity of effluents. Bis-trichloromethyl-sulfone does not degrade readily at neutral $\mathrm{pH}$ in aqueous solution but it volatilizes from open containers and is not likely to accumulate in receiving waters. On the other hand, isothiazolines appear stable in neutral $\mathrm{pH}$ and effluents containing high concentrations of this biocide require biological treatment before releasing to receiving waters.

\section{Toxicity analyses}

In industrial effluents, organic and inorganic compounds can be present at toxic levels which may cause disturbances in the processes and lead to violations of discharge permits (Sponza 2002; 2003). In some cases, potential toxicity may occur even though the actual level of toxicity is not exceeded and the discharge limits are not violated. There are numerous methods for the environmental monitoring and measuring the toxicity of effluents. The conventional approach is to use a set of physical and chemical parameters which indicate the state of the aquatic environment. Toxicity is often linked with the observed effects, such as mortality. In addition, the complex nature of wastewaters limits a complete chemical analysis and only biological tests can be used (Sponza 2003). The pollution is a complex matter and a sufficient number of indicative parameters are difficult to find. In addition, chemicals causing pollution comprise a vast number of substances of complex nature with possible synergistic effects which limits the use of chemical analyses. Even though the toxicity can be monitored by toxicological tests, it does not provide the cause of toxicity.

A number of biological assays have been developed for aquatic toxicity testing which is a rapidly growing field (Hayes et al. 1999; Sponza 2003). The tests provide information on the levels of toxicity and help to develop precautionary measures for environmental management. Conventional toxicity tests are routinely used to evaluate the toxicity of wastewater. For example, enrichment tests containing bacteria are used for identifying and categorizing toxic effluents. Living organisms respond well to the total effects of toxicity. Generally, the toxicity tests of pulp and paper mill effluents are performed with fish species, such as rainbow trout or salmon but also with cheaper Daphnia magna or Vibrio fischeri bacteria (Rigol et al. 2003a; Rigol et al. 2004). In addition, the toxicity tests of the most common resin and fatty acids and some biocides can be chemically characterized by LC-APCI-MS (Rigol et al. 2004).

The conventional toxicity tests in industrial use are time-consuming and the use of higher organisms as test species is ethically undesirable (Sponza 2002). Therefore bacterial and algal screening tests have been developed which are sensitive, rapid and inexpensive (Farré and Barceló 2001; Kovacs and Voss 1992). For example, bioassay, such as reverse electron transport (RET) assay is suitable for showing the toxicity of, e.g. lignin derivatives (Pessala et al. 2004). However, the tests do not give an insight of the causes of toxicity, and for that purpose, physical and chemical analyses are needed (Sponza 2002). There is no single method that can show a comprehensive approach and several tests containing sensitive microorganisms from different trophic levels are needed.

\section{Biodegradability and toxicity}

Biodegradability of a substance indicates the speed and efficiency of its degradation by microorganisms (Sponza 2003). If the $\mathrm{BOD}_{5} / \mathrm{COD}$ ratio is between 0.1-0.5 the substance 
is somewhat difficult to degrade and shows potential toxicity if released into the aquatic environment. Ratio between 5-9 indicates reduced biodegradability and severe toxicity. In some cases, the effluent can show potential toxicity even though the other effluent quality limits are ensured. On the other hand, effluents with COD levels exceeding limits may not show toxicity if the effluent contains large amount of readily biodegradable COD. Therefore, toxicity tests should be incorporated into the discharge standards. The algal, bacterial and fish tests are the most sensitive and should be applied for general toxicity testing. All toxicity tests have a viable role in water quality monitoring. However, there is no single test which gives a comprehensive approach. Especially, tests based on sensitive microorganisms should be applied to complement other tests and chemical analyses because they give information about potential toxicity practically and cost-effectively.

Resin acids and biocides in the bleached kraft pulp mill effluents are toxic with median lethal concentration $\left(\mathrm{LC}_{50}\right)$ for several fish species $<2 \mathrm{mg} / \mathrm{L}$ for resin acids and $<0.1 \mathrm{mg} / \mathrm{L}$ for biocides, such as methylene bisthiocyanate (MBT) and TCMTB (Reemtsma et al. 1995). In addition, toxicity values ( $\left.\mathrm{LC}_{50}\right)$ of biocides (TCMTB, MBT, and DBNPA) have been determined $0.24 \mathrm{mg} / \mathrm{L}$ for MTB, $0.37 \mathrm{mg} / \mathrm{L}$ for DBNPA and $0.039 \mathrm{mg} / \mathrm{L}$ for TCMTB (Rigol et al. 2004). The results show that the biocides are the most toxic compounds in paper mill circulation waters. However, the mixture of compounds exhibit lower toxic response compared to individual effects. Therefore, the evaluation of toxicity should include characterization of the mixture and its environmental impact and not only the impact of a single compound.

\section{Mutagenicity}

Mutagenicity of surface and industrial wastewaters can be studied with bioassays and analytical methods. However, evaluation of surface water mutagenicity provides only the indication of potential hazard not the exact toxicants or their properties (Ohe et al. 2004). Mutagenicity assessment commonly includes bacterial assays, aquatic organism assays, plant assays and ${ }^{32} \mathrm{P}$-postlabelling (Ohe et al. 2004). Genotoxic parameters, such as hepatic DNA adducts are valuable biomarkers for environmental risk assessment. Especially classes of Salmonella strains are sensitive to different chemicals and can be used for identification of genotoxicants in waters. The chemicals responsible for mutagenicity include heterocyclic aromatic amines derived from human feces, 2-phenylbenzotriazoletype (PBTA) from textile dying factories, hydroxyfuranones with mono-, di- and trichloromethyl groups from chlorine bleaching of pulp and 4-amino-3,3'-dichloro-5, $4^{\prime}$ dinitrobiphenyl from polymer and dye manufacturing (Shiozawa et al. 2000; Ohe et al. 2004; Franzén and Kronberg 1994).

Environmental mixtures contain unidentified and unregulated toxicants with potentially carcinogenic properties (Ohe et al. 2004). Genotoxic organic compounds can enter surface waters from industrial and municipal sources, such as treated or untreated discharges from chemical industries, accidental discharges, untreated domestic sludges and runoff of pesticides. Wastewater treatment processes do not remove all chemical contaminants effectively and the treatment processes may even increase mutagenicity or genotoxicity of wastewaters due to derivatives formed during water treatment processes (Claxton et al. 1998). 


\section{WASTEWATER TREATMENT PROCESSES}

\section{Biological treatment}

\section{Aerobic process}

Aerobic treatment is the most widely used technique to remove BOD and convert it to $\mathrm{CO}_{2}$ and water (Savant et al. 2006; Chanworrawoot and Hunsom 2012). The aerobic oxidation can be performed in e.g. aerated lagoon, aerated stabilization basin, activated sludge reactor or in sequential batch reactor (SBR) (Zhan et al. 2010). It facilitates the aeration, reaction and sludge settlement to occur in the same tank. In order to work properly, the concentration of dissolved oxygen needs controlling in the aeration tank.

Almost all wastewaters containing BOD/COD ratio of 0.5 or larger can be treated biologically (Chan et al. 2009). The biological aerobic treatment is used to remove BOD and COD even though their removal degree typically remains $20-50 \%$ due to highmolecular weight organic compounds (Villamar et al. 2009). The influent BOD needs to be high enough (300-700 $\mathrm{mg} / \mathrm{L}$ ) for effective functioning of the aerobic treatment process (Chan et al. 2009). A typical organic loading rate ranges from 0.07-0.21 kg BOD $/ \mathrm{kg}$ mixed liquor suspended solids (MLSS) (Thompson et al. 2001).

By aerobic treatment, 15-60\% of AOX (48-65\% AOX in mill scale) can be removed (Savant et al. 2006). LMW compounds (MW < 1000) are removed more effectively than the HMW (MW > 1000) compounds. The highest AOX removal rates $(80$ $\%$ ) have been achieved by the advanced aerobic reactors but with high energy requirement. The aerobic process is sensitive to shock loading and toxic compounds, has limited capacity to remove poorly biodegradable substances, such as lignin and lignin derivatives and produces sludge with variable settlement properties (Thompson et al. 2001; Chanworrawoot and Hunsom 2012).

Biological treatment (anaerobic and aerobic) is more economical compared to other methods and produces no secondary pollution (Sponza and Uluköy 2005). Aerobic processes are commonly used to treat effluents with low COD concentrations (COD $<1000$ $\mathrm{mg} / \mathrm{L}$ ) and anaerobic processes for the treatment of effluent with high COD strength (COD $>4000 \mathrm{mg} / \mathrm{L})$ (Seghezzo et al. 1998). Anaerobic process requires less energy compared to aerobic but combined with the aerobic system, well flocculated biomass, lower concentration of suspended solids and higher removal of biodegradable organic matter can be achieved.

Additionally, fungi can be used for the removal of BOD, COD and color. The chlorinated compounds are first incompletely degraded by fungi and subsequently by associative bacteria to complete the mineralization. Most of the chlorinated phenols and other LMW compounds are removed by the fungal treatment (Huynh et al. 1985). The most commonly used species of fungi are Phanerochaete chrysosporium and Coriolus versicolor (Bajpai and Bajpai 1997). The peroxidases and laccases of fungi oxidize the colored compounds and AOX of wastewaters. Even though the microbial systems can reduce toxicity, no commercially successful process has been developed.

\section{Anaerobic process}

Anaerobic treatment has been used for the handling of pulp and paper effluents since the 1970s (Savant et al. 2006). Anaerobic treatment is commonly technically simple, inexpensive and consumes little energy. In general, anaerobic process is performed in 
mesophilic temperatures, 35-37 ${ }^{\circ} \mathrm{C}$ but occasionally in thermophilic temperatures $\left(>45^{\circ} \mathrm{C}\right.$ ) which provides faster reaction rate and a higher amount of produced methane gas (Thompson et al. 2001). Compared to aerobic processes, it requires less space and produces smaller amount of sludge. It is capable of treating flows with high content of organics which cannot be degraded in the aerobic treatment process (Morgan-Samastume and Allen 2003). In addition, methane is produced during the anaerobic treatment, which can be used as fuel and can potentially improve the energy footprint of the mill. The nutrient requirement of an anaerobic process is low and the micro-organisms survive for long periods unfed. Therefore, it is a viable technology for the treatment of pulp and paper wastewaters. The main process options are anaerobic lagoon, anaerobic contact process, upflow anaerobic sludge blanket digestion (UASB), anaerobic filters and hybrid processes. Generally, the efficiency of anaerobic lagoons is very low and UASB and contact processes are the most widely used systems (Allen and Liu 1998). The upflow anaerobic sludge blanket (UASB) reactors can reach $70 \%$ COD removal from kraft pulp wastewater (Buzzini et al. 2005).

Anaerobic treatment of pulp and paper mill effluents is a cost-effective and technically simple technology which is able to remove $75-85 \%$ of BOD and $55-65 \%$ of COD (Savant et al. 2006; Nadeem 2012). However, the specific conditions and long retention times restrict their application. Among the existing technologies, anaerobic treatment is the only viable option for dechlorination of highly chlorinated compounds (Savant et al. 2006; Nadeem 2012). However, all anaerobic systems are unstable as regards AOX loading rates. In addition, high AOX loads inhibit the growth of methanogens in the reactor. In addition, anaerobic treatments are unable to remove the resin and fatty acids which are the main reason of fish toxicity of the TMP and CTMP effluents (Nadeem 2012). This has led to a two stage anaerobic-aerobic process to treat the pulp mill effluents and reduce the BOD loading. Even though physical and chemical methods have been studied, such as ultrafiltration to remove AOX and color, anaerobic treatment remains the most reliable and economical option. However, the high sulfur content of pulp and paper mill effluents may not be the most appropriate for the anaerobic treatment because of the potential for hydrogen sulfide production (Thompson et al. 2001). On the other hand, the effect of high concentrations of $\mathrm{Ca}^{2+}$ and $\mathrm{SO}^{4-}$ are more important (Hamm et al. 1991).

The upflow anaerobic filter (UAF) has a number of advantages compared to other anaerobic processes (Deshmukh et al. 2009). UAF provides shorter startup period, smaller reaction volume and stable operation under various process conditions. It is suitable for waste with low suspended solids content and requires no mechanical mixing (Speece 1996). In anaerobic processes dechlorination is often performed via co-metabolisms and halorespiration which requires input of electrons to replace chlorine (Dolfing 1990). The electrons are needed for the reductive dehalogenation reaction and generated from the oxidation of $\mathrm{H}_{2}$ from the fermentation of organic compounds, such as glucose, acetate and butyrate. By adding electron donor supplements to the process, the conditions remain thermodynamically favorable (Doong et al. 1996).

AOX degradation can be improved by glucose supplement (Ali and Sreekrishnan 2000). However, there are studies reporting insignificant effects have been published as well (Peijeie and Thomas 1994). UAF process degrades AOX more efficiently and a higher number of compounds compared to other biological processes. UAF does not require mechanical agitation or aeration which allows lower operating costs. Therefore, the single treatment with electron donor supplement is a better option compared to other physical, 
chemical or biological processes for the degradation of AOX in pulp and paper mill wastewaters.

\section{Chemical treatment}

There are plenty of physical, chemical and biological treatment technologies aiming at removing COD, BOD, AOX and color from the pulp and paper mill effluents (Nadeem 2012). Chemical methods include e.g. oxidation processes, such as photocatalysis and ozonation, and electrochemical processes.

\section{Oxidation processes}

Effluents can be treated with advanced oxidation processes aiming at degradation of organic pollutants and complete mineralization (Cuzzola et al. 2002). Advanced oxidation processes (AOP) include ozonation, Fenton reaction, UV irradiation, peroxide handling and their combinations (Rodrigues et al. 2008). AOPs are known to be able to mineralize a variety of organic compounds (Lucas et al. 2012). They generate highly reactive radicals, such as the hydroxyl radical (HO·) (Litter 2005). Fenton and solar photo-Fenton are known to be able to treat wastewater containing polyphenols, from e.g. pulp and paper industry. In addition, the photo-Fenton process is promising for the treatment of recalcitrant organic compounds (Suty et al. 2004). Photocatalysis can eliminate refractory residues known as photo-oxidation and photodegradation methods (Rodrigues et al. 2008). However, the initial COD value needs to be lower than $800 \mathrm{mg} \mathrm{L}^{-1}$. The use of sunlight is also an economical source of irradiation and tempting for commercial use (Malato et al. 2009). The effluent from a pulp mill contains a high organic load even after two biological treatment steps (Lucas et al. 2012). In case of non-biodegradable residue, AOPs are considered the best option for the treatment of effluent. With solar photo-Fenton removal rates of COD and total polyphenols more than $90 \%$ can be achieved.

Pretreatment step of the photocatalytic oxidation enhances the biodegradability of wastewater and is an alternative treatment to reach the total mineralization (Moiseev et al. 2004). For example, peroxide or ozone treatment increases the biodegradability of kraft mill effluents. Complete detoxification and removal of COD of bleached kraft pulp effluent can be achieved with ozone dosages of 0.5-1 kg/ADT of pulp (Hostachy et al. 1997). On the other hand, ozonation can be combined with a biodegradation in a biofilm reactor to achieve elimination of AOX and color. However, the main problem with chemical methods is that they produce large amounts of sludge which is difficult to dispose.

Wastewater can be treated by coagulation followed photocatalysis (Rodrigues et al. 2008). $\mathrm{TiO}_{2}, \mathrm{ZnO}, \mathrm{CeO}_{2}, \mathrm{CdS}$ or $\mathrm{ZnS}$ can be utilized as catalysts in the UV treatment which causes a large amount of radicals to be formed on the surface of catalyst yielding many compounds to degrade. Especially $\mathrm{TiO}_{2}$ is widely employed because of its non-toxicity and photo-stability in a wide range of $\mathrm{pH}$ (Machado et al. 2003). The photocatalytic reaction occurs when the semiconductor is activated by light and a band gap is generated. In case of $\mathrm{TiO}_{2}$, the energy for the band gap is $3.2 \mathrm{eV}$ which can be achieved at wavelengths shorter than $390 \mathrm{~nm}$. The addition of $\mathrm{H}_{2} \mathrm{O}_{2}$ to the $\mathrm{UV} / \mathrm{TiO}_{2}$ system increases the velocity of the photolysis. $\mathrm{UV} / \mathrm{TiO}_{2} / \mathrm{H}_{2} \mathrm{O}_{2}$ has been reported to be more efficient compared to $\mathrm{UV} / \mathrm{TiO}_{2}$, $\mathrm{UV} / \mathrm{H}_{2} \mathrm{O}_{2}$ or UV (Rodrigues et al. 2008). The combination of methods reduces the organic charge and the number of inorganic pollutants. After the treatment the effluent can be biologically degraded.

Many of AOPs are successful in lowering the AOX content in industrial wastewater from pulp and paper mills (Catalkaya and Kargi 2007). However, elevated levels of AOX 
have been reported after $\mathrm{UV} / \mathrm{H}_{2} \mathrm{O}_{2}$ treatment of synthetic wastewaters (Baycan et al. 2007). The increase is related to the concentration of chloride ions in the water. Therefore, the use of AOPs for the elimination AOX is not obvious in case of high chloride ion concentrations. Chlorine ions can react with hydroxyl radicals forming chlorine radicals. When the chlorine radicals react with organic matter, more AOX is generated. In case of ozone-based treatments, molecular ozone reacts with present chlorine ions forming hypochlorite and its conjugated acids (Luyten et al. 2013). These can subsequently react with organic material forming AOX.

Both matrix compounds and halogenated compounds compete for the oxidant and the formation of halogenated by-products is increased resulting increase of AOX (Luyten et al. 2013). Furthermore, the $\mathrm{pH}$ of water has an effect on the AOX concentration. Mineralization at elevated $\mathrm{pH}$ leads to formation of $\mathrm{CO}_{3}{ }^{2-}$ and $\mathrm{HCO}_{3}{ }^{-}$ions which are chlorine radical scavengers (Mertens and von Sonntag 1995). Therefore, less AOX is expected with high $\mathrm{pH}$ values. On the other hand, degradation of organic material may slow down because the formed $\mathrm{CO}_{3}{ }^{2-}$ and $\mathrm{HCO}_{3}{ }^{-}$radicals are known scavengers of hydroxyl radical. To achieve a significant reduction of both $\mathrm{COD}$ and $\mathrm{AOX}$, appropriate $\mathrm{AOP}, \mathrm{pH}$ and oxidant dosage are crucial factors if the effluent contains relatively high concentrations of halogen ions.

In conclusion, the AOX of industrial effluent can be significantly reduced by a combined biological and chemical treatment (Luyten et al. 2013). Generally, less AOX is removed by $\mathrm{O}_{3}$-based treatments compared to $\mathrm{H}_{2} \mathrm{O}_{2}$-based. When combining AOPs with a biological treatment, high removal percentages are achieved because the AOX is not only degraded but transformed to components more available for biological oxidation. The most important parameter seems to be the oxidant concentration when selectivity towards AOX degradation is required.

\section{Electrochemical processes}

Wastewaters including organic and inorganic compounds can be treated with electrochemical methods which have advantages compared to chemical and biological methods (Uğurlu et al. 2008). For example, chemical oxidation methods require large amounts of reactive chemicals but electrochemical methods do not require harmful reagents. In addition, electrochemical reactions are relatively independent of the conditions of wastewater and require basically only the current to the electrode (Kuramitz et al. 2001).

Electrochemical methods can be applied to treatment of liquids, gases and solids (Uğurlu et al. 2008). Electrocoagulation creates a floc of metallic hydroxides with the effluent by electrodissolution of soluble anodes. Compared to traditional methods of flocculation and coagulation, it can remove even the smallest colloidal particles and produce a relatively low amount of sludge. In addition, the required equipment is simple and easily operated. Electrocoagulation has been used for the treatment of food and oil wastes but recently also for the treatment of pulp and paper mill effluents. Lignin, phenols, BOD and COD can be removed by the electrocoagulation from the effluent. The removal efficiency increases with increasing current intensity.

Electrochemical treatment has multiple applications for industrial wastewater purification (Chanworrawoot and Hunsom 2012). The kaolin catalyst can reach a higher level of COD removal in the combined electro-catalysis with the $\mathrm{Cu}_{2} \mathrm{O}-\mathrm{CoO}-\mathrm{PO}_{4}{ }^{3-}$ modified kaolin caused by the oxidant $(\mathrm{OH} \cdot)$ (Wang et al. 2011). $\mathrm{H}^{+}$can be produced by the electrochemical technique during the treatment instead of acid, such as $\mathrm{H}_{2} \mathrm{SO}_{4}$, which decreases the production of sludge, operating costs and contamination by the chemicals. 
The electrochemical method is efficient, requires only moderate operating costs and can increase the biodegradability index of the wastewater. However, the treatment efficiency is affected by the dilution, circulating water flow rate, density and concentration of sodium chloride. High process efficiency is reached at low flow rates.

A partial removal of AOX can be achieved through nucleophilic substitution reactions in alkaline sulfide and alkaline hydrolysis processes (Zheng and Grant 1997). However, they are limited by the high costs and generation of air emissions or sludge. In addition, reductive dechlorination of AOX has been suggested using zero-valent metal and bimetallic systems (Patel and Suresh 2006). Even though the reactions are fast, inhibitory co-pollutants may decrease the reaction rate drastically.

Chlorophenols, a major fraction of AOX, can be reduced electrochemically by sequential dechlorination leading to the accumulation of partially dechlorinated hydrocarbon product (e.g. phenol) (Nadeem et al. 2012; Cui et al. 2005). However, application of electrochemical reduction requires a separating membrane between the anode and cathode. The membranes can be fouled by wastewater which limits their application. On the other hand, chlorophenols can be completely destructed by electrochemical oxidation (Polcaro and Palmas 1997). Oxidation can be achieved in divided or undivided cells and the extent of treatment depends mainly on the type of anode and the reaction conditions. For example, iron or aluminium anode leads to formation of electrochemical sludge of variety of metal hydroxide species (Mahesh et al. 2006). However, use of a non-sacrificial anode eliminates the formation of sludge and provides a simple process with low operation costs.

The electrocoagulation cell consists of electrodes and a power source (Mollah et al. 2001). The anodes are made of iron or aluminum and the cathode from an inert material such as titanium. The degree of hydrolysis depends on the $\mathrm{pH}$ of the solution. Anions, such as sulfate or chloride are not needed with metal cations and hydroxides in the EC process. Hydrogen is produced at the cathode which causes the flotation and the separation of agglomerated particles from water. The $\mathrm{pH}$ of water increases during electrocoagulation but typical chemical coagulants decrease the water $\mathrm{pH}$.

Electrocoagulation can also be used to remove pollutants, such as wood rosin, copper and resin acids from pulp mill effluents (Vepsäläinen et al. 2011). The method enhances the removal of resin acids in the subsequent filtration stage at $\mathrm{pH}$. The pimaric acids are removed more efficiently than the resin acids. In addition, copper can be efficiently removed but also color with long treatment time and high $\mathrm{pH}$. However, the EC has no clear effect on bacterial toxicity. The toxicity is associated with the color and as the color is removed, the toxicity decreases as well. It can be concluded that the EC combined with separation technologies such as filtration or sedimentation is suitable for the removal of toxic pollutants from pulp mill effluents. However, optimization of the method requires further research.

\section{Physical treatment}

Effluent from pulp and paper industry requires proper purification before releasing into natural waters (Lucas et al. 2012). Even then it may cause e.g. thermal impacts, slime growth, color and aesthetic problems and death of zooplankton and fish (Pokhrel and Viraraghavan 2004). Most pulp and paper mills use conventional processes for the purification of effluents including physical and biological methods. The common physical treatment processes constitute a primary clarification (e.g. sedimentation, flotation), secondary treatment, such as activated sludge process and tertiary processes including 
membrane processes (Chanworrawoot and Hunsom 2012). However, they do not lead to complete degradation of organic matter (Gönder et al. 2011).

Waters from pulp mills can be treated by e.g. evaporation (Dahl 1999), membrane processes (Tavares et al. 2002), adsorption, ion-exchange, coagulation and flocculation (Brown et al. 1999). Coagulation and flocculation are the most used physical wastewater treatment methods (Rodrigues et al. 2008). A cationic metal can be used as a coagulant agent that promotes formation of hydrophobic substances or polymeric compounds. The coagulant agents react with colloidal materials by adsorption or by charge neutralization leading eventually to sedimentation. The effectiveness of a coagulant depends on type of coagulant, concentration, $\mathrm{pH}$ and ionic strength and dosage (Delgado et al. 2003; Leiviskä and Rämö 2008). Often, the coagulation and flocculation processes have been evaluated by measuring the color reduction, UV absorbance, total organic carbon (TOC), turbidity, dissolved organic carbon (DOC), adsorbable organic halogen (AOX) and chlorinated phenols (Beulker and Jekel 1993). However, the amount of residual wood extractives are rarely been measured.

The extractives can be removed by flocculation with polyethylene oxide or by cationic polyelectrolytes (Rampotas 1999; Leiviskä and Rämö 2008). In addition, polyelectrolytes can be used as internal or external treatment but also as supplemental to biological treatment to decrease the amount of extractives. For example, chitosan can be added to enhance the coagulation but chitosan can also be used independently as a coagulant (Bratskaya et al. 2004). However, addition of chitosan does not decrease significantly the COD load and absorbance but does improve the sedimentation velocity and compaction. Lower amount of sludge is formed compared to inorganic coagulants and the sludge has better fuel properties since it contains less ash and inorganics. However, their toxicity and biodegradability needs careful studying because of the toxic nature of anionic polymers (Guida et al. 2004). Cationic polymers need to be selective and retain the beneficial compounds, such as carbohydrates in the process. The filtrates from bleaching are often high in $\mathrm{pH}$ which needs to be reduced because acidic conditions ( $\mathrm{pH} 5.5)$ are needed for the coagulation-flocculation treatment.

The wastewater treatment processes at pulp and paper mills include primary clarification following secondary treatment, generally a biological treatment (Thompson et al. 2001). Tertiary processes include further treatment or color removal. Physical techniques constitute e.g. adsorption, ultrafiltration, nanofiltration and reverse osmosis (Nadeem 2012). Primary clarification can be performed by sedimentation or flotation which provides high removal $(>80 \%)$ of suspended solids. However, in case of paper mill effluents only a small fraction of organic material (BOD and COD) is removed. Even treated paper mill effluents may contain color which originates from lignin.

The main tertiary treatment processes include membrane processes, such as ultrafiltration which is a pressure-drived separation through a membrane. Ultrafiltration and reverse osmosis with pressures of 3.5-5.5 MPa yield almost total separation of AOX but they require pretreatment steps and a lot of energy (Savant et al. 2006). In addition, fouling of membranes may become a problem. In addition to traditional treatment processes, there are also novel chemical and physical methods (Uĝurlu et al. 2008). For example, filtration through soil, lime precipitation, ion exchange chromatography and ultrafiltration have been tested but no commercial applications are yet in operation (Ali and Sreekrishnan 2001).

Finally, supercritical water oxidation is also been suggested for the removal of AOX. The pressurized waste stream is heated with an oxidant to a temperature above the critical point of water $\left(374{ }^{\circ} \mathrm{C}\right)$ which allows the organic waste to oxidize (Allen and Liu 
1998). The inorganics can be easily separated after the treatment. In addition, chlorine and hypochlorite generated by the electrolysis of chlorides can be used to oxidize organic compounds in the effluents (Savant et al. 2006). However, the treatment is high in operation costs due to underdeveloped technology and undesirable side reactions.

\section{SUMMARY AND OUTLOOK}

Industrial wastewaters from pulp and paper mills contain harmful components, such as wood derived resin and fatty acids, betulinol, lignin derivatives and process chemicals, such as biocides but also compounds classified as dangerous chemicals e.g. dioxins, furans and polychlorinated biphenyls. Even though most of the harmful substances are removed by the modern wastewater purification processes, some are still released into the environment. Traditionally, industrial wastewaters have been treated with mechanical technologies followed by biological and/or chemical methods. However, wastewaters from pulp and paper mills contain recalcitrant organic material, such as lignin and lignin derivatives which raise the need for additional treatment methods. Therefore, variety of novel chemical methods has been introduced, such as electrochemical and oxidation processes. These methods are able to degrade even the most stable organic pollutants and even lead to their complete mineralization.

Compounds in industrial wastewaters are analyzed with variety of methods. However, chromatographic methods are the most widely used, including GC or LC coupled to FID, MS or MS/MS depending on the analyte. Pulp and paper mill effluents are often toxic to aquatic environment even after the water purification processes. A variety of biological assays have been developed for the assessment of toxicity. Living organisms are often used in toxicity tests since they respond well to the total effects of toxicity. However, the current trend is to use bacterial or other lower level organisms instead of fish due to lower costs and ethical reasons. No single method is able to give a comprehensive approach and therefore, several tests containing sensitive microorganisms from different trophic levels are needed.

\section{Acknowledgement}

This work was financially supported by Maa ja vesitekniikan tuki ry. 


\section{REFERENCES CITED}

Abrantes S, Philo M, Damant AP, Castle L (1998) Determination of extractable biocides in paper food packaging materials using micellar electrokinetic chromatography.

J Microcolumn Sep 10:387-391

Adams SM, Crumby WD, Greeley MS, Shugatr LR, Saylor CF (1992) Responses of fish populations and communities to pulp mill effluents: A holistic assessment. Ecotox Environ Safe 24:347-360

Adler E (1977) Lignin chemistry - past, present and future. Wood Sci Technol 11:169-218

Aguera A, Piedra L, Hernando MD, Fernandez-Alba AR (2000) Multiresidue method for the analysis of five antifouling agents in marine and coastal waters by gas chromatography-mass spectrometry with large-volume injection. J Chromatogr A 889:261-269

Ahtiainen J, Ruoppa M, Nakari T, Verta M (2003) Toxicity screening of novel pulping influents and effluents in Finnish pulp mills. In: Stuthridge TR, van den Heuvel MR, Marvin NA, Slade AH, Gifford J (eds) Environmental impacts of pulp and paper waste streams. SETAC Press, Pensacola, pp 96-100

Alakurtti S, Mäkelä T, Koskimies S, Yli-Kauhaluoma J (2006) Pharmacological properties of the ubiquitous natural product botulin. Eur J Pharm Sci 29:1-13

Alén R (2000) Structure and chemical composition of wood. In: Stenius P (ed.) Forest products chemistry, Fapet Oy, Helsinki, pp 11-57

Ali M, Sreekrishnan TR (2000) Anaerobic treatment of agricultural residue based pulp and paper mill effluents for AOX and COD reduction. Process Biochem 36:25-29

Ali M, Sreekrishnan TR (2001) Aquatic toxicity from pulp and paper mill effluents: a review. Adv Environ Res 5:175-196

Allen DG, Liu HW (1998) Pulp mill effluent remediation. In: Meyers, RA (ed) Encyclopedia of environmental analysis and remediation. Wiley, New York, pp 3871-3887

Allen DG, Konduru RR, Liss SN (2001) Recalcitrant organics emerging from biological treatment of Kraft mill effluents. Water Qual Res J Can 36:737-757

Andreozzi R, Caprio V, Marotta R, Radovnikovic A (2003) Ozonation and $\mathrm{H}_{2} \mathrm{O}_{2} / \mathrm{UV}$ treatment of clofibric acid in water: a kinetic investigation. J Hazard Mater B103:233-246

Appling JW, Cruickshank GA, DeLong RF, Herschler RJ, Humiston CG, Martin RB, Sanborn JR, Shema BF, Wiley AJ (1955) Microbiology of pulp and paper. Tappi Monograph series No. 15, New York

Astudillo L, Rodriguez JA, Schmeda-Hirschmann G (2002) Gastroprotective activity of oleanolic acid derivatives on experimentally induced gastric lesions in rats and mice. J Pharm Pharmacol 54:583-588

Ayebo A, Breuer GM, Cain TG, Wichman MD, Subramanian P, Reynolds SJ (2006) Sterols as bio-markers for waste impact and source characterization in stream sediment. J Environ Health 68:46-50

Back EL, Ekman R (2000) Definitions of wood resin and its components. In: Back EEL, Allen LH (eds) Pitch control, wood resin and deresination, Tappi Press, Atlanta, pp vii-xi

Bajpai P, Bajpai PK (1997) Reduction of organochlorine compounds in bleach plant effluent. Adv Biochem Technol Biotechnol 57:213-259 
Baycan N, Thomanetz E, Sengül F (2007) Effect of chloride concentration on the oxidation of EDTA in UV-FSR oxidative system. J Photochem Photobiol A 189:349-354

Belsare DK, Prasad DY (1988) Decolorization of effluent from the bagasse based pulp mills by white rot fungus Trametes versicolor. Process Biochem 46:274-276

Benitez FJ, Acero JL, Gonzalez T, Garcia J (2001) Ozonation and biodegradation processes in batch reactors treating black table olives washing wastewaters. Ind Eng Chem Res 40:3144-3151

Beulker S, Jekel M (1993) Precipitation and coagulation of organic substances in bleachery effluents of pulp mills. Water Sci Technol 27:193-199

Blair A, Dosemeci M, Heineman EF (1993) Cancer and other causes of death among male and female farmers from twenty-three states. Am J Ind Med 23:729-742

Bratskaya S, Schwarz S, Chervonetsky D (2004) Comparative study of humic acids flocculation with chitosan hydrochloride and chitosan glutamate. Water Res 38:2955-2961

Brezny R, Joyce T, Gonzalez B, Slimak M (1993) Biotransformations and toxicity changes of chlorolignins in soil. Environ Sci Technol 27:1880-1884

Brown CJ, Sheedy M, Paleologou M, Thompson R (1999) Ion-exchange technologies for the minimum effluent kraft mill. Pulp Paper Can 100:31-36

Brownlee BG, Carey JH, MacInnis GA, Pellizzari IT (1992) Aquatic environmental chemistry of 2-(thiocyanomethylthio)benzothiazole and related benzothiazoles. Environ Toxicol Chem 11:1153-1168

Brownlee BG, MacInnis GA, Noton LR (1993) Chlorinated anisoles and veratroles in a Canadian river receiving bleached kraft pulp mill effluent. Identification, distribution, and olfactory evaluation. Environ Sci Technol 1093: 2450-2455

Butler ECV, Dal Pont G (1992) Liquid chromatography-electrochemistry procedure for the determination of chlorophenolic compounds in pulp mill effluents and receiving waters. J Chromatograph 609:113-123.

Buzzini AP, Gianotti EP, Pires EC (2005) UASB performance for bleached and unbleached kraft pulp synthetic wastewater treatment. Chemosphere 59:55-61.

Catalkaya EC, Kargi F (2007) Color, TOC and AOX removal from pulp mill effluent by advanced oxidation processes: A comparative study. J Hazard Mater B 139:244-253

Chan YJ, Chong MF, Law CL, Hassell DG (2009) A review on anaerobic-aerobic treatment of industrial and municipal wastewater. Chem Eng J 155:1-18

Chanworrawoot K, Hunsom M (2012) Treatment of wastewater from pulp and paper mill industry by electrochemical methods in membrane reactor. J Environ Manage 113:399-406

Chelme-Ayala P, Gamal El-Din M, Smith DW (2010) Degradation of bromoxynil trifluralin in natural water by direct photolysis and UV plus $\mathrm{H}_{2} \mathrm{O}_{2}$ advanced oxidation processes. Water Res 44:2221-2228

Chen C-M (2004) The emission inventory of PCDD/PCDF in Taiwan. Chemosphere 54:1413-1420

Chen Z-F, Ying G-G, Lai H-J, Chen F, Su H-C, Liu Y-S, Peng F-Q, Zhao J-L (2012) Determination of biocides in different environmental matrices by use of ultra-highperformance liquid chromatography-tandem mass spectrometry. Anal Bioanal Chem 404:3175-3188

Chen L, Xie B, Li L, Jiang W, Zhang Y, Fu J, Guan G, Qiu Y (2014) Rapid and sensitive LC-MS/MS analysis of fatty acids in clinical samples. Chromatographia 77:1241-1247 
Christianson-Heiska I, Haavisto T, Paranko J, Bergelin E, Isomaa B (2008) Effects of the wood extractives dehydroabietic acid and betulinol on reproductive physiology of zebrafish (Danio rerio)-A two generation study. Aquat Toxicol 86:388-396

Claxton LD, Houk VS, Hughes TJ (1998) Genotoxicity of industrial waste and effluents. Mutat Res 410: 237-243

Cloete TE, Jacobs L, Brozel VS (1998) The chemical control of biofouling in industrial water systems. Biodegradation 9:32-37

Criado MR, Pombo da Torre S, Rodríguez Pereiro I, Cela Torrijos R (2004) Optimization of a microwave-assisted derivatization-extraction procedure for the determination of chlorophenols in ash samples. J Chromatogr A 1024:155-163

Cserjesi AJ, Johnson EL (1982) Mold and sapstain control: Laboratory and field tests of 44 fungicidal solutions. Forest Prod J 32:59-68

Cui C, Quan X, Chen S, Zhao H (2005) Adsorption and electro catalytic dechlorination of pentachlorophenol on palladium-loaded activated carbon fibers. Sep Purif Technol 47:73-79

Cuzzola A, Bernini M, Salvadori P (2002) A preliminary study on iron species as heterogeneous catalysts for the degradation of linear alkylbenzene sulphonic acids by $\mathrm{H}_{2} \mathrm{O}_{2}$. Appl Catal B: Environ 36:231-237

Dahl O (1999) Evaporation of acidic effluent from kraft pulp bleaching, reuse of the condensate and further processing of the concentrate. Dissertation, University of Oulu

Daniels CR, Swan EP (1987) P.HPLCAssay of the anti-stain chemical TCMTB applied to lumber surfaces. J Chromatogr Sci 25:43-45

Davy CW (2004) Legislation with respect to dioxins in the workplace. Environ Int 30:219-233

de Morais P, Stoichev T, Basto MCP, Vasconcelos MTSD (2012) Extraction and preconcentration techniques for chromatographic determination of chlorophenols in environmental and food samples. Talanta 89:1-11

De Wever HD, Verachtert H (1997) Biodegradation and toxicity of benzothiazoles. Water Res 31:2673-2684

Delgado S, Diaz F, Garcia D, Otero N (2003) Behaviour of inorganic coagulants in secondary effluents from a conventional wastewater treatment plant. Filtr Sep 40:43-46.

Demirbaş G, Gökcay C.F, Dilek FB (1999) Treatment of organic chlorine in pulping effluents by activated sludge. Water Sci Technol 40:275-279

Desai ID (1992) Downstream processing. In: Mukherjee RN (ed) Biotechnology proceedings of an international seminar, Tata McGraw-Hill, New Delhi

Deshmukh NS, Lapsiya KL, Savant DV, Chiplonkar SA, Yeole TY, Dhakephalkar PK, Ranade DR (2009) Upflow anaerobic filter for the degradation of adsorbable organic halides (AOX) from bleach composite wastewater of pulp and paper industry. Chemosphere 75:1179-1185

Dethlefs F, Stan HJ (1996) Determination of resin acids in pulp mill EOP bleaching process effluent. Fresenius J Anal Chem 356:403-410

Dolfing J (1990) Reductive dechlorination of 3-chloro-benzoate is coupled to ATP production and growth in an anaerobic bacterium, DCB-1. Arch Microbiol 153:264-266

Doong R-A, Chen T-F, Chang W-H (1996) Effects of electron donor and microbial concentration on the enhanced dechlorination of carbon tetrachloride by anaerobic consortia. Appl Microbiol Biot 46:183-186

Dyer JC, Mignone NA (1983) Handbook of industrial residues. Vol. 1. Environmental Engineering Series, Noyes publications, Park Ridge, NJ 
Eckerman C, Ekman R (1985) Comparison of solvents for extraction and crystallization of betulinol from birch bark waste. Paperi ja Puu 67:100-106

Eiznhamer DA, Xu ZQ (2004) Betulinic acid: a promising anticancer candidate. IDrugs, 7:359-373

Ekman R, Holmbom B (1989) Analysis by gas chromatography of the wood extractives in pulp and paper samples from mechanical pulping of spruce. Nord Pulp Pap Res J. 4:16-24

El-Shahawi MS, Hamza A, Bashammakh AS, Al-Saggaf WT (2010) An overview on the accumulation, distribution, transformations, toxicity and analytical methods for the monitoring of persistent organic pollutants. Talanta 80:1587-1597

Fardim P, Gustafsson J, von Schoultz S, Peltonen J, Holmbom B (2005) Extractives on fiber surfaces investigated by XPS, ToF-SIMS and AFM. Colloids Surf A: Physicochem Eng Asp 255:91-103

Farré M, Barceló D (2001) Characterization of wastewater toxicity by means of a whole cell bacterial biosensor using Pseudomonas putida in conjunction with chemical analysis. Fresenius J Anal Chem 371:467-473

Farstad L, Naess B (1977) Effects of alkali lignins on some biological systems. Acta Agric Scand 27:123-128

Fengel D, Wegener G (1989) Wood-chemistry, ultrastructure, reactions. Walter de Gruyter, Berlin

Franzén R, Kronberg L (1994) Determination of chlorinated 5-methyl-5-hydroxyfuranones in drinking water, in chlorinated humic water, and in pulp bleaching liquor. Environ Sci Technol 28:2222-2227

Freeman NCG, de Tejada SS (2002) Methods for collecting time/ activity pattern information related to exposure to combustion products. Chemosphere 49:979-992

Fueno H, Tanaka K, Sugawa S (2002) Theoretical study of the dechlorination reaction pathways of octachlorodibenzo-p-dioxin. Chemosphere 48:771-778

Fujioka T, Kashiwada Y, Kilkuskie RE, Cosentino LM, Ballas LM, Jiang JB, Janzen WP, Chen I-S, Lee K-H (1994) Anti-AIDS agents, 11. Betulinic acid and platanic acid as anti-HIV principles from Syzigium claviflorum, and the anti-HIV activity of structurally related triterpenoids. J Nat Prod 57:243-247

Griffiths NM, Fenwick GR (1977) Odour properties of chloroanisoles-effects of replacing chloro- by methyl groups. Chem Senses 2:487-491

Grimvall A, Borén H, Jonsson S, Karlsson S, Sävenhed R (1991) Organohalogens of natural and industrial origin in large recipients of bleach-plant effluents. Water Sci Technol 24:373-383

Guida, M, Mattei M, Melluso G, Pagano G, Meric S (2004) Daphnia magna and Selenastrum capricornutum in evaluating the toxicity of alum and polymer used in coagulation-flocculation. Fresenius Environ Bull 13:1244-1247

Gönder ZB, Arayici S, Barlas H (2011) Advanced treatment of pulp and paper mill wastewater by nanofiltration process: effects of operating conditions on membrane fouling. Sep Purif Technol 76:292-302

Hamm U, Bobek B, Gottsching L (1991) Anaerobic treatment of waste-water from wastepaper converting paper-mills. Das Papier 45:V55-V63

Hanaki K (1981) Mechanism of inhibition caused by long chain fatty acids in anaerobic digestion process. Biotechnol Bioeng XXIII:1591-1610

Hanssen HW, Henderson ND (1991) A review of the environmental impact and toxic effects of 2-MBT. Environmental protection division, Victoria, BC 
Hayes E, Woods C, Lockett P (1999) Toxicity testing in the textile industry: an evaluation of current methods. International Conference on Water and Textile, London, pp 48-56

Heimberger SA, Blevins DS, Bostwick JH, Donnini GP (1988) Kraft bleach mill plant effluents: recent developments aimed at decreasing their environmental impact, part 1. Tappi J Oct:51-59

Herve SH (1991). Mussel incubation method for monitoring organochlorine compounds in freshwater recipients of pulp and paper industry. Dissertation, University of Jyväskylä

Hewitt LM, Parrott JL, McMaster ME (2006) A decade of research on the environmental impacts of pulp and paper mill effluents in Canada: Sources and characteristics of bioactive substances. J Toxicol Environ Health B 9:341-356

Hileman B (1994) Environmental estrogens linked to reproductive abnormalities and cancer. Chem Eng News 31:19-23

Hillis WE (1971) Distribution, properties and formation of some wood extractives. Wood Sci Technol 5:272-289

Hollert H, Dürr M, Haag I, Wölz J, Hilscherova K, Blaha L, Gerbersdorf SU (2007) Influence of hydrodynamics on sediment ecotoxicity. Westrich B, Förstner U (eds.) Sediment dynamics and pollutant mobility in rivers. Springer, Berlin, pp 401-416

Holmbom S (1980) A procedure for analysis of toxic compounds in pulp and paper mill waste waters. Paperi ja puu 9:523-531

Holmbom B (1999) Extractives. In: Sjöström E, Alén R (eds) Analytical methods in wood chemistry, pulping and papermaking. Springer-Verlag, Berlin pp 125-148

Holmbom S, Stenius P (2000) Analytical methods. In: Stenius, P (ed) Papermaking science and technology forest products chemistry, Fapet Oy, Jyväskylä, pp 106-169

Holt E, Von Der Recke R, Vetter W, Hawker D, Alberts V, Kuch B, Weber R, Gaus C (2008) Assessing dioxin precursors in pesticide formulations and environmental samples as a source of octachlorodibenzo-p-dioxin in soil and sediment. Environ Sci Technol 42:1472-1478

Hostachy JC, Lenon G, Pisicchio JL, Coste G, Legay C (1997) Reduction of pulp and paper mill pollution by ozone treatment. Water Sci Technol 35:261-268

Huntscha S, Singera HP, McArdella CS, Franka CE, Hollender J (2012) Multiresidue analysis of 88 polar organic micropollutants in ground, surface and wastewater using online mixed-bed multilayer solid-phase extraction coupled to high performance liquid chromatography-tandem mass spectrometry. J Chromatograph A 1268:74-83

Huynh VB, Chang HM, Joyce TW, Kirk TK (1985) Dechlorination of chloro-organics by a white rot fungus. Tappi J 68:98-102

Hynynen J, Palomäki A, Meriläinen JJ, Witick A, Mäntykoski K (2004) Pollution history and recovery of a boreal lake exposed to a heavy bleached pulping effluent load. J Paleolimnol 32:351-374

Häggblom MM, Nohynek LJ, Salkinoja-Salonen MS (1988) Degradation and Omethylation of chlorinated phenolic compounds by Rhodococcus and Mycobacterium strains. Appl Environ Microbiol 54:3043-3052

Jäger S, Laszczyk MN, Scheffler A (2008) A Preliminary pharmacokinetic study of betulin, the main pentacyclic triterpene from extract of outer bark of birch (Betulae alba cortex). Molecules 13:3224-3235

Kantiani L, Farré M, Asperger D, Rubio F, González S, López de Alda MJ, Petrović M, Shelver WL, Barceló D (2008) Triclosan and methyl-triclosan monitoring study in the northeast of Spain using a magnetic particle enzyme immunoassay and confirmatory analysis by gas chromatography-mass spectrometry. J Hydrol 361:1-9 
Kaplin C, Hemming J, Holmbom B (1997) Improved water quality by process renewal in a pulp and paper mill. Boreal Environ Res 2:239-246

Kim H, Masaki H, Matsumura T, Kamei T, Magara Y (2002) Removal efficiency and homologue patterns of dioxins in drinking water treatment. Water Res 36:4861-4869

Kingstad KP, Lindstrom K (1984) Spent liquors from pulp bleaching. Environ Sci Technol $18: 236-247$

Kitsiou V, Filippidis N, Mantzavinos D, Poulios I (2009) Heterogeneous and homogeneous photocatalytic degradation of the insecticide imidacloprid in aqueous solutions. Appl Catal B Environ 86:27-35

Kitunen VH (1990) The use and formation of CPs, PCPPs and PCDD/PCDFs in mechanical and chemical wood processing industries. Dissertation, University of Helsinki

Knuutinen J, Tarhanen J, Lahtiperä M (1982) Gas chromatographic and mass spectrometric analysis of chlorinated catechols occurring in pulp bleach liquors. Chromatographia 15:9-12

Koistinen J, Lehtonen M, Tukia K, Soimasuo M, Lahtiperä M, Oikari A (1998) Identification of lipophilic pollutants discharged from a Finnish pulp mill. Chemosphere 37:219-235

Kolari M (2003) Attachment mechanisms and properties of bacterial biofilms on non-living surfaces. Dissertation, University of Helsinki

Kostamo A, Kukkonen JVK (2003) Removal of resin acids and sterols from pulp mill effluents by activated sludge treatment. Water Res 37:2813-2820

Kostamo A, Holmbom B, Kukkonen JVK (2004) Fate of wood extractives in wastewater treatment plants at kraft pulp mills and mechanical pulp mills. Water Res 38:972-982

Kovacs TG, Voss RH (1992) Biological and chemical characterization of newsprint/specialty mill effluents. Water Res 26:771-780

Kringstad KP, Lindström K (1984) Spent liquors from pulp bleaching. Environ Sci Technol 18:236A-248A

Kruzynski GM, Birtwell IK (1994) A predation bioassay to quantify the ecological significance of sublethal responses of juvenile Chinook salmon (Oncorhynchus tshawytscha) to the antisapstain fungicide TCMTB. Can J Fish Aquat Sci 51:1780-1790

Kukkola J, Knuutinen J, Paasivirta J, Herve S, Pessala P, Schultz E (2011) Size-exclusion chromatographic study of ECF and TCF softwood kraft pulp bleaching liquors. Environ Sci Pollut Res 18:1049-1056

Kukkonen J (1992) Effects of lignin and chlorolignin in pulp mill effluents on the binding and bioavailability of hydrophobic organic pollutants. Water Res 26:1523-1532

Kumar A, Dhall P, Kumar R (2010) Redefining BOD: COD ratio of pulp mill industrial wastewaters in BOD analysis by formulating a specific microbial seed. Int Biodeter Biodegr 64:197-202

Kuramitz H, Nakata Y, Kawasaki M, Tanaka S (2001) Electrochemical oxidation of bisphenol A. Application to the removal of bisphenol A using a carbon fiber electrode. Chemosphere 45:37-43

Lahdelma I, Oikari A (2006) Stratigraphy of wood-derived sterols in sediments historically contaminated by pulp and paper mill effluents. J Paleolimnol 35:323-334

Landner L, Lindström K, Karlsson M, Nordin J, Sörensen L (1977) Bioaccumulation in fish of chlorinated phenols from kraft pulp mill bleachery effluents. Bull Environ Contam Toxicol 18:663-673 
Latorre A, Rigol A, Lacorte S, Barceló D (2003) Comparison of gas chromatography-mass spectrometry and liquid chromatography-mass spectrometry for the determination of fatty and resin acids in paper mill process waters. J Chromatogr A 991:205-215

Latorre A, Rigol A, Lacorte S, Barceló D (2005) Organic compounds in paper mill wastewaters. In: Hutzinger O (ed) The handbook of environmental chemistry, vol. 5. Springer, Berlin, pp 25-51

Leach JM (1980) Loadings and effects of chlorinated organics from bleached pulp mills. In: Jolley RL, Brings WA, Cumming RB, Jacob VA (eds) Water chlorination: Environmental impact and health effects, 3. Ann Arbor Science, Ann Arbor, pp 325-334

Lee EG, Mueller JC, Walden CC (1978) Decolorization of bleached kraft mill effluents by algae. Tappi J 61:59-62

Lee JM, Kim JH, Chang YY, Chang YS (2009) Steel dust catalysis for Fenton-like oxidation of polychlorinated dibenzo-p-dioxins. J Hazard Mater 163:222-230

Lei L, Chen S, Li Y (2013) Effect of biological treatment on characteristics of soluble organic compounds in hardwood KP bleaching effluent. Bioresources 8:4349-4358

Leiviskä T, Rämö J (2008) Coagulation of wood extractives in chemical pulp bleaching filtrate by cationic polyelectrolytes. J Hazard Mater 153:525-531

Leiviskä T, Nurmesniemi H, Pöykiö R, Rämö J, Kuokkanen T, Pellinen J (2008) Effect of biological wastewater treatment on the molecular weight distribution of soluble organic compounds and on the reduction of BOD, COD and $\mathrm{P}$ in pulp and paper mill effluent. Water Res 42:3952-3960

Leiviskä T, Sarpola A, Tanskanen J (2012) Removal of lipophilic extractives from debarking wastewater by adsorption on kaolin or enhanced coagulation with chitosan and kaolin. Appl Clay Sci 61:22-28

Lewis R, van Leeuwen JA, Smernik RJ, Chow CWK, Everson A, Nothrop SC, Beecham S (2011) Changes in the organic character of post-coagulated Pinus radiate sulfite pulp mill wastewater under aerated stabilization basin treatment - a laboratory scale study. Chem Eng J 175:160-168

Lewis R, Nothrop S, Chow CWK, Everson A, van Leeuwen JA (2013) Colour formation from pre and post-coagulation treatment of Pinus radiata sulfite pulp mill wastewater using nutrient limited aerated stabilisation basins. Sep Purif Technol 114:1-10

Liess M, Von der Ohe PC (2005) Analyzing effects of pesticides on invertebrate communities in streams. Environ Toxicol Chem 24:954-965

Lin C-J, Zhang P, Pongprueksa P, Liu J, Evers SA, Hart P (2013) Pilot-scale sequential anaerobic-aerobic biological treatment of waste streams from a paper mill. Environ Prog Sustain Energy 33:359-368

Lindholm PC, Knuutinen JS, Ahkola HSJ, Herve SH (2014) Analysis of trace pharmaceuticals and related compounds in municipal wastewaters by preconcentration, chromatography, derivatization, and separation methods. BioResources 9:3688-3732

Litter MI (2005) Introduction to photochemical advanced oxidation processes for water treatment. In: Boule P, Bahnemann DW, Robertson PKJ (eds) Environmental photochemistry, vol. 2. Springer-Verlag, Berlin, pp 325-366

Lucas MS, Peres JA, Amor C, Prieto-Rodríguez L, Maldonado MI, Malato S (2012) Tertiary treatment of pulp mill wastewater by solar photo-Fenton. J Hazard Mater 225-226:173-181

Luthe CE, Voss RH, Berry RM (1995) Tracking dioxins: From chips to finished product. Chemosphere 30:661-670 
Luthe CE (1996) Octachlorinated dioxin in pulps and effluents: Where does it come from? Chemosphere 32:2409-2425

Luyten J, Sniegowski K, Van Eyck K, Maertens D, Timmermans S, Liers S, Braeken L (2013) AOX removal from industrial wastewaters using advanced oxidation processes: assessment of a combined chemical-biological oxidation. Water Sci Technol 68:2048-2054

Maatela P, Paasivirta J, Särkkä J, Paukku R (1990) Organic chlorine compounds in lake sediments and the role of the chlorobleaching effluents. Chemosphere 21:1343-1354

Machado AEH, Miranda JA, Freitas RF, Duarte ETFM, Ferreira LF, Albuquerque YDT, Ruggiero R, Sattler C, Oliveira L (2003) Destruction of the organic matter present in effluent from a cellulose and paper industry using photocatalysis. J Photochem Photobiol A Chem 155:231-241

Mahesh S, Prasad B, Mall ID, Mishra IM (2006) Electrochemical degradation of pulp and paper mill wastewater. Part 1. COD and color removal. Ind Eng Chem Res 45:2830-2839

Malato S, Fernández-Ibáñez P, Maldonado MI, Blanco J, Gernjak W (2009) Decontamination and disinfection of water by solar photocatalysis: recent overview and trends. Catal Today 147:1-59

Malisch R (2000) Increase of the PCDD/F-contamination of milk, butter and meat samples by use of contaminated citrus pulp. Chemosphere 40:1041-1053

Matilainen A, Vepsäläinen M, Sillanpää M (2010) Natural organic matter removal by coagulation during drinking water treatment: a review. Adv Colloid Interface Sci 159:189-197

Mattson K, Lehtinen K-J, Tana J, Harding J, Kukkonen J, Nakari T, Engström C (2001) Effects of pulp mill effluents and restricted diet on growth and physiology of rainbow trout (Oncorhynchus mykiss). Ecotox Environ Safe 49:144-154

McCoy J (1980) Microbiology of cooling water. Chemical Publishing Co, New York

McMartin DW, Peru KM, Headley JV, Winkler M, Gillies JA (2002). Evaluation of liquid chromatography-negative ion electrospray mass spectrometry for the determination of selected resin acids in river water. J Chromatogr A 952:289-293

Meding B, Toren K, Karlberg A-T, Hagberg S, Wass K (1993). Evaluation of skin symptoms among workers at a Swedish paper mill. Am J Ind Med 23:721-728

Mellanen P, Petänen T, Lehtimäki J, Mäkelä S, Bylund G, Holmbom B, Mannila E, Oikari A, Santti R (1996) Wood-derived estrogens: studies in vitro with breast cancer cell lines and in vivo in trout. Toxicol Appl Pharmacol 136:381-388

Meriläinen P, Lahdelma I, Oikari L, Hyötyläinen T, Oikari A (2006) Dissolution of resin acids, retene and wood sterols from contaminated lake sediments. Chemosphere 65:840-846

Meriläinen P, Oikari A (2008) Uptake of organic xenobiotics by benthic invertebrates from sediment contaminated by the pulp and paper industry. Water Res 42:1715-1725

Mertens R, von Sonntag C (1995) Photolysis $(\lambda=254 \mathrm{~nm})$ of tetrachloroethene in aqueous solutions. J Photochem Photobiol A: Chem 85:1-9

Michałowicz J, Duda W (2007) Phenols - sources and toxicity. Polish J Environ Stud $16: 347-362$

Milanova E, Sitholé BB (1997) Acute toxicity to fish and solution stability of some biocides used in the pulp and paper industry. Wat Sci Tech 35:373-380

Moghaddam MG, Ahmad FBH, Samzadeh-Kermani A (2012) Biological activity of betulinic acid: a review. Pharmacol Pharm 3:119-123 
Moiseev A, Schroeder H, Kotsaridou-Nagel M, Geissen SU, Vogelpohl A (2004) Photocatalytical polishing of paper-mill effluents. Water Sci Technol 49:325-330

Mollah MY, Schennach R, Parga J, Cocke DL (2001) Electrocoagulation (EC)-science and applications. J Hazard Mater B 84:29-41

Morgan-Sagastume F, Allen DG (2003) Effects of temperature transient conditions on aerobic biological treatment of wastewater. Water Res 37:3590-3601

Mosbye J, Harstad B, Fiksdahl A (2000) Solid phase extraction (SPE) of hydrophobic components from a model white water. Nordic Pulp Paper Res J 15:101-105

Munkittrick KR, McMaster ME, McCarthy LH, Servos MR, Van Der Kraak GJ (1998) An overview of recent studies on the potential of pulp mill effluents to impact reproductive function in fish. J Toxicol Environ Health B 1:347-371

Mörck R., Björklund Jansson M, Dahlman O (2000) Resinous compounds in effluents from pulp mills. In: Back EL, Allen LH (eds) Pitch control, wood resin and deresination. Tappi Press, Atlanta, pp 245-263

Nadeem KA (2012) Various treatment processes for the removal of absorbable organic halides (AOX) from pulp and paper industry wastewater. Int J Res Chem Environ 2:22-27

Naru M, Goto M, Kato H, Oshima Y (1993) Study on endocrine disrupting chemicals in wastewater treatment plants. Water Sci Technol 43:101-108

Nawrocki ST, Drake KD, Watson CF, Foster GD, Maier KJ (2005) Comparative aquatic toxicity evaluation of 2-(thiocyanomethylthio)benzothiazole and selected degradation products using Ceriodaphnia dubia. Arch Environ Contam Toxicol 48:344-350

Niu J, Chen J, Henkelmann B, Quan X, Yang F, Kettrup A, Schramm KW (2003) Photodegradation of PCDD/Fs adsorbed on spruce (Picea abies (L.) Karst.) needles under sunlight irradiation. Chemosphere 50:1217-1225

Ohe T, Watanabe T, Wakabayashi K (2004) Mutagens in surface waters: a review. Mutat Res 567:109-149

Oikari A, Lönn B-E, Castrén M, Nakari T, Snickars-Nikinmaa B, Bister H, Virtanen E (1983) Toxicological effects of dehydroabietic acid (DHAA) on the trout, Salmo gairdneri Richardson, in fresh water. Water Res 17:81-89

Oikari A, Lindström-Seppä P, Kukkonen J (1988) Subchronic metabolic effects and toxicity of a simulated pulp mill effluent on juvenile lake trout, Salmo trutta m. lacustris. Ecotoxicol Environ Safe 16:202-218

Oller I, Malato S, Sánchez-Pérez JA (2011) Combination of advanced oxidation processes and biological treatments for wastewater decontamination-A review. Sci Total Environ 409:4141-4166

Paasivirta J (1978) Kloorifenolit-myrkkyjä, ehkä ympäristömyrkkyjä (chlorophenolspoisons, possible environmental poisons). Kemia-kemi 5:367-370

Paasivirta J, Knuutinen J, Tarhanen J, Kuokkanen T, Surma-Aho K, Paukku R, Kääriäinen H, Lahtiperä M, Veijanen A (1983) Potential off-flavour compounds from chlorobleaching of pulp and chlorodisinfection of water. Water Sci Technol 15:97-104

Paasivirta J, Klein P, Knuutila M, Knuutinen J, Lahtiperä M, Paukku R, Veijanen A, Welling L, Vuorinen PJ (1987) Chlorinated anisoles and veratroles in fish. Model compounds. Instrumental and sensory determinations. Chemosphere 16:1231-1241

Paasivirta J, Knuutinen J, Maatela P, Paukku R, Soikkeli J, Särkkä J (1988) Organic chlorine compounds in lake sediments and the role of the chlorobleaching effluents. Chemosphere 17:137-146 
Paasivirta J, Tenhola H, Palm H, Lammi R (1992) Free and bound chlorophenols in kraft pulp bleaching effluents. Chemosphere 24:1253-1258

Palm H, Paasivirta J, Lammi R (1995) Behaviour of chlorinated phenolic compounds in bleach plant treatment-system and archipelago area. Chemosphere 31:2839-2852

Pan L, Pawliszyn J (1997) Derivatization/solid-phase microextraction: New approach to polar analytes. Anal Chem 69:196-205

Patel UD, Suresh S (2006) Dechlorination of chlorophenols by magnesium-silver bimetallic system. J Colloid Interface Sci 299:249-259

Peijeie Y, Thomas W (1994) Anaerobic treatment of kraft bleaching plant effluent. Appl Microbiol Biot 40:806-811

Peng G, Roberts JC (2000a) Solubility and toxicity of resin acids. Water Res 34:2779-2785

Peng G, Roberts JC (2000b) An improved method for analyzing resin acid in wood, pulp, process water and effluent samples. Tappi J 83: 80-81

Pepper IL, Gerba CP, Brusseau ML (1996) Pollution Science. Academic Press, San Diego

Pera-Titus M, García-Molina V, Baños MA, Giménez J, Esplugas S (2004) Degradation of chlorophenols by means of advanced oxidation processes: a general review. Appl Catal B - Environ 47:219-256

Pereira MO, Vieira MJ, Beleza VM, Melo LF (2001) Comparison of two biocides carbamate and glutaraldehyde- in the control of fouling in pulp and paper industry. Environ Technol 22:781-790

Pessala P, Schultz E, Nakari T, Joutti A, Herve S (2004) Evaluation of wastewater effluents by small-scale biotests and afractionation procedure. Ecotoxicol Environ Safe 59:263-272

Pessala P, Schultz E, Kukkola J, Nakari T, Knuutinen J, Herve S, Paasivirta J (2010) Biological effects of high molecular weight lignin derivatives. Ecotoxicol Environ Safe 73:1641-1645

Petrović M, Eljarrat E, López de Alda MJ, Barceló D (2001) Analysis and environmental levels of endocrine disrupting compounds in freshwater sediments. TRAC-Trend Anal Chem 20:637-648

Pisha E, Chai H, Lee IS, Chagwedera TE, Farnsworth NR, Cordell GA, Beecher CWW, Fong HHS, Kinghorn AD, Brown DM, Wani MC, Wall ME, Hieken TJ, Das Gupta TK, Pezzuto JM (1995) Discovery of betulinic acid as a selective inhibitor of human melanoma that functions by induction of apoptosis. Nat Med 1:1046-1051

Pokhrel D, Viraraghavan T (2004) Treatment of pulp and paper mill wastewater - a review. Sci Total Environ 333:37-58

Polcaro AM, Palmas S (1997) Electrochemical oxidation of chlorophenols. Ind Eng Chem Res 36:1791-1798

Pomerantz I, Burke J, Firestone D, McKinney J, Roach J, Trotter W (1978) Chemistry of PCBs and PBBS. Environ Health Perspect 24:133-146

Popa V, Teaca C-A (1998) Influence of chlorolignin products on wheat plants (Triticum astivum L.) growth and development. In: International conference on biotechnology in the pulp and paper industry, Canadian pulp and paper association, Technical section, Montreal, pp C231-C233

Priha MH, Talka ET (1986) Biological activity of bleached kraft mill effluent (BKME) fractions and process streams. Pulp Paper Can 87:447-449

Rafoth A, Gabriel S, Sacher F, Brauch HJ (2007) Analysis of isothiazolinones in environmental waters by gas chromatography-mass spectrometry. J Chromatogr A $1164: 74-81$ 
Rampotas C (1999) Kidney technology in kraft mills. Paper Eqpmt Mater Int 1:928-929

Ratia H, Vuori K-M, Oikari A (2012) Caddis larvae (Trichoptera, Hydropsychidae) indicate delaying recovery of a watercourse polluted by pulp and paper industry. Ecol Indic 15:217-226

Ratia H, Rämänen H, Lensu A, Oikari A (2013) Betulinol and wood sterols in sediments contaminated by pulp and paper mill effluents: dissolution and spatial distribution. Environ Sci Pollut Res 20:4562-4573

Raymond L, Gagné A, Talbot J, Gratton R (1998) Pitch deposition in a fine paper mill. Pulp Paper Can 99:71-74

Redenbach AE (1997) Sensory evaluation of fish exposed to pulp and paper mill effluent: a case study of method used for environmental effects monitoring. Water Sci Technol $35: 357-363$

Reemtsma T, Fiehn O, Kalnowski G, Jekel M (1995) Microbial transformations and biological effects of fungicide-derived benzothiazoles determined in industrial wastewater. Environ Sci Technol 29:478-485

Remberger M, Allard A-S, Neilson AH (1986) Biotransformations of chloroguajacols, chlorocathecols and chloroveratroles in sediments. Appl Environ Microbiol 51:552-558

Renberg L, Svanberg O, Bengsson B-E, Sundström G (1980) Chlorinated guajacols and cathecols. Bioaccumulation potential in bleaks (Alburnus alburnus, Pisces) and reproductive and toxic effects on the harpacticoid Nitora snipes (Crustacea). Chemosphere 9:143-150

Rigol A, Latorre A, Lacorte S, Barceló D (2002) Determination of toxic compounds in paper-recycling process waters by gas chromatography-mass spectrometry and liquid chromatography-mass spectrometry. J Chromatogr A 963:265-275

Rigol A, Lacorte S, Barcelo D (2003a) Sample handling and analytical protocols for analysis of resin acids in process waters and effluents from pulp and paper mills. Trends Anal Chem 22:738-749

Rigol A, Latorre A, Lacorte S, Barceló D (2003b) Direct determination of resin and fatty acids in process waters of paper industries by liquid chromatography/mass spectrometry. J Mass Spectrom 38:417-426

Rigol A, Latorre A, Lacorte S, Barceló D (2004) Bioluminescence inhibition assays for toxicity screening of wood extractives and biocides in paper mill process waters. Environ Toxicol Chem 23:339-347

Rissanen E, Krumschnabel G, Nikinmaa M (2003) Dehydroabietic acid, a major component of wood industry effluents, interferes with cellular energetics in rainbow trout hepacytes. Aquat Toxicol 62:45-53

Robertson LR, Schwingel WR (1997) Effect of water reuse on paper machine microbiology. In: Proceedings of the 1997 Environmental conference, vol. 1. Tappi Press, Norcross, pp 87-93

Rodrigues AC, Boroski M, Shimada NS, Garcia JC, Nozaki J, Hioka N (2008) Treatment of paper pulp and paper mill wastewater by coagulation-flocculation followed by heterogeneous photocatalysis. J Photoch Photobio A 194:1-10

Rämänen H, Lassila H, Lensu A, Lahti M, Oikari A (2010) Dissolution and spatial distribution of resin acids and retene in sediments contaminated by pulp and paper industry. J Soil Sediment 10:349-358

Salina O, Alakurtti S, Pohjala L, Siiskonen A, Maass V, Maass M, Yli-Kauhaluoma J, Vuorela P (2010) Inhibitory effect of the natural product betulin and its derivatives 
against the intracellular bacterium Chlamydia pneumonia. Biochem Pharmacol 80:1141-1151

Sanborn JR (1965) Slime control in the pulp and paper industry. Lockwood Trade Journal Co., New York

Santa T, Al-Dirbashi OY, Ichibangase T, Fukushima T, Rashed MS, Funatsu T, Imai K (2007) Synthesis of benzofurazan derivatization reagents for carboxylic acids in liquid chromatography/electrospray ionization-tandem mass spectrometry. Biomed Chromatogr 21:1207-1213

Sarkanen KV, Ludwig CH (1971) Lignins: occurrence, formation, structure and reactions. Wiley, New York

Saski EK, Mikkola R, Kukkonen JVK, Salkinoja-Salonen MS (1997) Bleached kraft pulp mill discharged organic matter in recipient lake sediment. Environ Sci Pollut Res 4:194-202

Sastry CA (1986) Colour removal from pulp and paper mill wastewaters. Indian J Environ Prot 6:105-113

Savant DV, Abdul-Rahman R, Ranade DR (2006) Anaerobic degradation of adsorbable organic halides (AOX) from pulp and paper industry wastewater. Biores Technol 97:1092-1104

Schaechter TM, Lederberg J (2004) The desk encyclopedia of microbiology. Elsevier academic press, London

Seghezzo L, Zeeman G, van Lier JB, Hamelers HVM, Lettinga G (1998) A review: The anaerobic treatment of sewage in UASB and EGSB reactors. Biores Technol $65: 175-190$

Sharma A, Kumar A, Kumar R, Gangal SV, Gangal V, Makhijani SD (1996) Assessment of biodegradability of organic acids by a defined microbial mixture. Bull Environ Contam Toxicol 57:34-40

Shimp RJ, Owens JW (1993) Pulp and paper technologies and improvements in environmental emissions to aquatic environments. Toxicol Environ Chem 40:213-233

Shiozawa T, Tada A, Nukaya H, Watanabe T, Takahashi Y, Asanoma M, Ohe T, Sawanishi H, Katsuhara T, Sugimura T, Wakabayashi K, Terao Y (2000) Isolation and identification of a new 2-phenylbenzotriazole-type mutagen (PBTA-3) in the Nikko River in Aichi, Japan. Chem Res Toxicol 13:535-540

Sierra-Alvarez R, Lettinga G (1991) The methanogenic toxicity of wastewater lignins and lignin related compounds. J Chem Technol Biotechnol 50:443-455

Sierra-Alvarez R, Field JA, Kortekaas S, Lettinga G (1994) Overview of the anaerobic toxicity caused by forest industry wastewater pollutants. Water Sci Technol 29:353-363

Sinkkonen S, Kolehmainen E, Paasivirta J, Koistinen J, Lahtiperä M, Lammi R (1994) Identification and level estimation of chlorinated neutral aromatic sulfur compounds and their alkylated derivatives in pulp mill effluents and sediments. Chemosphere 28:2049-2066

Sitholé B (2007) Pulp and paper matrices analysis: Introduction. In: Myers RA (ed) Encyclopedia of analytical chemistry. Applications, theory and instrumentation, Pulp and paper, vol. 9. Wiley, West Sussex, pp 1-9

Sjöström E (1984) Wood chemistry. Academic Press, New York

Skark C, Zullei-Seibert N, Willme U, Gatzemann U, Schlett C (2004) Contribution of nonagricultural pesticides to pesticide load in surface water. Pest Manag Sci 60:525-530

Slawson RM, Van Dyke MI, Lee H, Trevors JT (1992). Gemanium and silver resistance accumulation and toxicity in microorganisms. Plasmid 27:72-79 
Sorrelle PH, Belgrad WE (1992) Growth in recycling escalates costs for paper machine biological control. Pulp paper 66:57-64

Speece RE (1996) Anaerobic biotechnology for industrial wastewaters. Archae Press, Nashville

Speksnijdera P, van Ravestijna J, de Voogt P (2010) Trace analysis of isothiazolinones in water samples by large-volume direct injection liquid chromatography tandem mass spectrometry. J Chromatogr A 1217:5184-5189

Sponza DT (2002) Incorporation of toxicity tests into the Turkish industrial discharge monitoring systems. Arch Environ Contam Toxicol 43:186-197

Sponza DT (2003) Application of toxicity tests into discharges of the pulp-paper industry in Turkey. Ecotox Environ Safe 54:74-86

Sponza DT, Uluköy A (2005) Treatment of 2,4-dichlorophenol (DCP) in a sequential anaerobic (upflow anaerobic sludge blanket) aerobic (completely stirred tank) reactor system. Process Biochem 40:3419-3428

Srogi K (2008) Levels and congener distributions of PCDDs, PCDFs and dioxin-like PCBs in environmental and human samples: a review. Environ Chem Lett 6:1-28

Stahlschmidt-Allner P, Allner B, Römbke J, Knacker T (1997) Endocrine disrupters in the aquatic environment. Environ Sci Pollut Res 4:155-162

Sun YB, Joyce TW, Chang HM (1989) Dechlorination and decolorization of high molecular weight chlorolignins from bleach plant effluents by an oxidation process. Tappi J Sept:209-213

Suty H, De Traversay C, Cost M (2004) Applications of advanced oxidation processes: present and future. Water Sci Technol 49:227-233

Södergren A, Bengtsson BE, Jonsson P, Lagergren S, Larson A, Olsson M, Renberg L (1988) Summary of results from the Swedish project Environment/ Cellulose. Water Sci Technol 20:49-60

Tana J, Lehtinen K-J (1996) Valkaistun massan tuotannosta aiheutuvien jätevesien ympäristövaikutusten arviointi - yleiskatsaus. (in Finnish). Suomen Ympäristökeskuksen moniste 20:1-25.

Tavares CR, Vieira M, Petrus JCC, Bortoletto EC, Ceravollo F (2002) Ultrafiltration/ complexation process for metal removal from pulp and paper industry wastewater. Desalination 144:261-265

Temmink JHM, Field JA, van Haastrecht JC, Merkelbach RCM (1989) Acute and subacute toxicity of bark tannins in carp (Cyprinus carpio L.). Water Res 23:341-344

Thompson G, Swain J, Kay M, Forster CF (2001) The treatment of pulp and paper mill effluent: a review. Biores Technol 77:275-286

Tremblay L, van der Kraak G (1999) Comparison between the effects of the phytosterol $\beta$ itosterol and pulp and paper mill effluents on sexually immature rainbow trout. Environ Toxicol Chem 18:329-336

Tuomela M, Vikman M, Hatakka A, Itävaara M (2000) Biodegradation of lignin in a compost environment: a review. Biores Technol 72:169-183

Uğurlu M, Gürses A, Doĝar Ç, Yalçin M (2008) The removal of lignin and phenol from paper mill effluents by electrocoagulation. J Environ Manage 87:420-428

Vallejo M, San Román MF, Ortiz I, Irabien A (2015) Overview of the PCDD/Fs degradation potential and formation risk in the application of advanced oxidation processes (AOPs) to wastewater treatment. Chemosphere 118:44-56

Valto P, Knuutinen J, Alén R (2008) Fast analysis of relative levels of dehydroabietic acid in papermaking process waters by on-line sample enrichment followed by atmospheric 
pressure chemical ionisation-mass spectrometry (APCI-MS). Intern J Environ Anal Chem 88:969-978

Valto P, Knuutinen J, Alén R (2009) Evaluation of resin and fatty acid concentration levels by online sample enrichment followed by atmospheric pressure chemical ionizationmass spectrometry (APCI-MS). Environ Sci Pollut Res 16:287-294

Valto P, Knuutinen J, Alén R (2012) Overview of analytical procedures for fatty and resin acids in the papermaking process. Bioresources 7:6041-6076

Van den Berg M, Birnbaum LS, Denison M, De Vito M, Farland W, Feeley M et al (2006) The 2005 World Health Organization reevaluation of human and mammalian toxic equivalency factors for dioxin and dioxin-like compounds. Toxicol Sci 93:223-241

Vehniäinen E-R, Häkkinen J, Oikari A (2003) Photoinduced lethal and sublethal toxicity of retene, a polycyclic aromatic hydrocarbon derived from resin acid, to coregonid larvae. Environ Toxicol Chem 22:2995-3000

Veningerová M, Prachar V, Uhnák J, Kovacicová J (1994) Polychlorinated phenols in total diet. Z Lebensm Unters Forsch 199:317-321

Vepsäläinen M, Kivisaari H, Pulliainen M, Oikari A, Sillanpää M (2011) Removal of toxic pollutants from pulp mill effluents by electrocoagulation. Sep Purif Technol 81:141-150.

Villamar CA, Jarpa M, Decap J, Vidal G (2009) Aerobic moving bed bioreactor performance: A comparative study of removal efficiencies of kraft mill effluents from Pinus radiata and Eucalyptus globulus as raw material. Water Sci Technol 59:507-514

Vincent-Hubert F, Heas-Moisan K, Munschy C, Tronczynski J (2012) Mutagenicity and genotoxicity of suspended particulate matter in the Seine river estuary. Mutat Res 741:7-12

Voss RH, Rapsomatiotis A (1985) An improved solvent-extraction based procedure for the gas chromatographic analysis of resin and fatty acids in pulp mill effluents. J Chromatogr 346:205-214

Walden CC, Howard TE (1977) Toxicity of pulp and paper mill effluents - a review of regulations and research. Tappi J 60:122-125

Wang JP, Chen YZ, Wang Y, Yuan SJ, Yu HQ (2011) Optimization of the coagulationflocculation process for pulp mill wastewater treatment using a combination of uniform design and response surface methodology. Water Res 45:5633-5640

Weber R (2007) Relevance of PCDD/PCDF formation for the evaluation of POPs destruction technologies - review on current status and assessment gaps. Chemosphere 67:S109-S117

Werker AG, Hall ER (1999a) The influence of $\mathrm{pH}$ on the growth linked biodegradation kinetics of selected resin acids found in pulp mill effluent. Tappi J 82:169-177

Werker AG, Hall ER (1999b) Limitations for biological removal of resin acids from pulp mill effluent. Water Sci Technol 40:281-288

White PA, Rasmussen JB, Blaise C (1998) Genotoxic substances in the St. Lawrence system I: industrial genotoxins sorbed to particulate matter in the St. Lawrence, St. Maurice, and Saguenay Rivers, Canada. Environ Toxicol Chem 17:286-303

Wilhelm DK, Makris SP, Banerjee S (1999) Signature of recalsitrant stickies in recycled newsprint mills. Tappi J 82:63-66

Zacharewski TR, Berhane K, Gillesby BE (1995) Detection of estrogen and dioxin-like activity in pulp and paper mill black liquor and effluent using in vitro recombinant receptor/reporter gene assay. Environ Sci Technol 29:2140-2146 
Zanella E (1983) Effect of $\mathrm{pH}$ on acute toxicity of dehydroabietic acid and chlorinated dehydroabietic acid to fish and Daphnia. Bull Environm Contam Toxicol 30:133-140

Zhan P, Chen J, He G, Fang G, Shi Y (2010) Microbial dynamics in a sequencing batch reactor treating alkaline peroxide mechanical pulp and paper process wastewater. Environ Sci Pollut Res 17:1599-1605

Zheng Y, Grant AD (1997) The effect of pre-hydrolysis of D-stage filtrate on the biotreatability of chlorinated organic compounds in bleached Kraft mill effluents. Water Res 31:595-600

Örså F, Holmbom BJ (1994) A convenient method for the determination of wood extractives in papermaking process waters and effluents. J Pulp Paper Sci 20: J361-J365 